\title{
Atrial Natriuretic Peptide Type C Induces a Cell-Cycle Switch from Proliferation to Differentiation in Brain-Derived Neurotrophic Factor- or Nerve Growth Factor-Primed Olfactory Receptor Neurons
}

\author{
P. Jeanette Simpson, ${ }^{1}$ lan Miller, ${ }^{1}$ Cheil Moon, ${ }^{1}$ Andrea L. Hanlon, ${ }^{1}$ Daniel J. Liebl, ${ }^{3}$ and Gabriele V. Ronnett ${ }^{1,2}$ \\ Departments of ${ }^{1}$ Neuroscience and ${ }^{2}$ Neurology, The Johns Hopkins University School of Medicine, Baltimore, Maryland \\ 21205, and ${ }^{3}$ Department of Neurosurgery, The Miami Project to Cure Paralysis, University of Miami School of Medicine, \\ Miami, Florida 33136
}

\begin{abstract}
With the discovery of postnatal stem cells within the brain, it has become important to understand how extracellular factors might affect the maturation of neuronal precursors in the postnatal brain. Neurotrophic factors are known to play a role in neuronal development but display pleiotrophic effects, in part because of their physiological interactions with other factors. One factor positioned to interact with neurotrophins in the brains of postnatal animals is atrial C-type natriuretic peptide (CNP). In this study, we used olfactory receptor neurons (ORNs) as a model, because their precursors demonstrate the most robust and functional postnatal neurogenesis of those systems thus far described. We examined the effects of brain-derived neurotrophic factor (BDNF) and nerve growth factor (NGF) and the interactions of these neurotrophins and CNP in postnatal
\end{abstract}

olfactory neuronal precursors. Results obtained using mice with targeted deletion of the gene for BDNF indicated that BDNF is a neuroproliferation-inducing and survival factor for ORN precursors. These roles were confirmed in vitro using primary cultures of ORNs. NGF was found to be a proliferation-inducing factor but not a survival factor. The addition of CNP to either BDNF- or NGF-treated neuronal precursors resulted in an inhibition of proliferation and the promotion of maturation. These effects were accompanied by changes in cell-cycle proteins that suggest possible mechanisms for these effects. Thus, CNP may function in the postnatal brain to regulate the exit from the cell cycle in neuronal precursor cells.

Key words: olfactory receptor neurons; neurotrophins; neurogenesis; atrial natriuretic peptide type C; olfaction; cell cycle
The discovery of stem cells in the adult brain that can develop into mature neurons in vitro suggests that postnatal neurogenesis could be used to repopulate certain neuronal lineages (Shetty and Turner, 1998, 1999). Many factors have been implicated in neuronal precursor proliferation and maturation, including neurotrophins, neuropeptides, and cytokines (Abe, 2000; Rosser et al., 2000). Although the proliferation of neuronal stem cells can be induced in vitro by certain mitogens, the factors that mediate differentiation remain unclear (Learish et al., 2000; Miyazawa et al., 2000; Rosser et al., 2000). Identification of factors that regulate the neuronal life cycle, specifically those that modulate the maturation of neurons within the postnatal brain, is critical to the application of stem cell therapy (Thomson et al., 1998; Vogel, 1999; Edwards et al., 2000).

Atrial C-type natriuretic peptide (CNP) and its receptor, guanylyl cyclase receptor type B (GC-B), are positioned to play a role in prenatal and postnatal neurogenesis. CNP binds to GC-B to

\footnotetext{
Received Jan. 30, 2002; revised April 12, 2002; accepted April 19, 2002.

This work was supported by National Institute on Deafness and Other Communication Disorders Grant DC-2979 and National Institute of Neurological Disorders and Stroke Grant NS-39657 to G.V.R. and by National Institutes of Health National Research Service Award F32 DC 00406 to P.J.S. We thank Luis Parada (University of Texas at Southwestern, Dallas, TX), Valéry Matarazzo, Debby R. Cohen, and David Ginty for helpful discussions and reading of this manuscript, Kris Palczewski (University of Washington, Seattle, WA) for anti-GC-B antibodies, and Lana Kramer for manuscript preparation.

Correspondence should be addressed to Dr. Gabriele V. Ronnett, Department of Neuroscience, 1006B Preclinical Teaching Building, Johns Hopkins University School of Medicine, 725 North Wolfe Street, Baltimore, MD 21205. E-mail: gronnett@jhmi.edu.

Copyright (C) 2002 Society for Neuroscience $\quad 0270-6474 / 02 / 225536-16 \$ 15.00 / 0$
}

increase cGMP production. CNP mRNA has been found in various regions in the postnatal rat brain, notably in olfactory regions and in the hippocampus (Ryan and Gundlach, 1998), and GC-B mRNA is detected in many brain regions, including the limbic cortex, neocortex, olfactory bulb, hippocampus, and amygdala (Herman et al., 1996). GC-B is found in the cerebral cortex as early as embryonic day 16 (E16) (Brown and Zuo, 1995), a stage during which cortical neurogenesis occurs (Bayer and Altman, 1995).

The roles of CNP and cGMP in the brain are unclear. Although CNP is known for its role in fluid and electrolyte balance (Langub et al., 1995), some work suggests a developmental role for this peptide in the brain (Brown and Zuo, 1995). CNP as well as other atrial natriuretic peptides antagonize mitogen-stimulated signaling pathways and proliferation in fibroblasts and thymocytes (Vollmar et al., 1996; Calderone et al., 1998; Chrisman and Garbers, 1999). CNP also inhibits growth factor-dependent DNA synthesis in response to basic FGF, epidermal growth factor (EGF), heparin-binding EGF-like growth factor, and plateletderived growth factor in smooth muscle cells, an effect that is mimicked by the application of 8-bromo-cGMP (Porter et al., 1992).

The peripheral olfactory system has long been recognized as a model of postnatal neurogenesis, because it displays the most robust and functional postnatal neurogenesis among neuronal populations that maintain stem cells (Graziadei and MontiGraziadei, 1978, 1979). In addition, neurogenesis is increased after lesioning of either the olfactory bulb (termed bulbectomy) 
or the epithelium itself (Constanzo, 1984). The epithelium contains a mixed population of basal cells, basal daughter cells, immature and mature olfactory receptor neurons (ORNs), and sustentacular cells (Morrison and Costanzo, 1990a,b; Uraih and Maronpot, 1990). Basal cells and their daughter cells generate the new neurons that repopulate the olfactory epithelium (OE) throughout life (Schultz, 1960; Graziadei and Monti-Graziadei, 1983; Morrison and Moran, 1995; Calof et al., 1998; Huard et al., 1998). Here, we refer to basal cells and their daughters as neuronal precursor cells.

Many factors involved in neurogenesis in the brain are also implicated in prenatal and postnatal neurogenesis in the olfactory epithelium. CNP is positioned to play a role in olfactory development, because GC-B mRNA is abundant in the olfactory epithelium (Fulle et al., 1995). CNP and GC-B are highly expressed in olfactory regions of the brain (Herman et al., 1996; Ryan and Gundlach, 1998), suggesting a potential role for CNP as a target-derived factor. In addition, BDNF, NGF, and their receptors [tyrosine kinase (Trk) B, Trk A, and p75] are found in the rodent olfactory epithelium in immature neurons and basal cells (Roskams et al., 1996). Their expression is upregulated after bulbectomy (Roskams et al., 1996; Buckland and Cunningham, 1998), suggesting a potential role in postnatal ORN proliferation. Both factors are able to stimulate c-fos when applied to ORNs in culture (Roskams et al., 1996).

In this study, we have used the olfactory system as a model for identifying factors that are involved in the switch from proliferation to maturation and in the survival of postnatal neuronal precursors. Mice with targeted deletion of the gene for BDNF were used to define the role(s) of BDNF in olfactory neuroproliferation and survival. Primary ORN cultures were used to confirm these results and to study signaling mechanisms (Ronnett et al., 1991). The proliferation-inducing role of NGF was also characterized. CNP and GC-B were localized in the olfactory epithelium and bulb, and their ability to promote the differentiation and survival of neurotrophin-treated ORNs was determined.

\section{MATERIALS AND METHODS}

Animals. All animal use procedures were in strict accordance with institutional guidelines for the care and use of laboratory animals at Johns Hopkins University. Transgenic C57BL/6 mice heterozygous for BDNF deletions were obtained from the University of Texas Southwestern Medical Center (Dallas, TX) (Liebl et al., 1997). These mice were bred to obtain heterozygous BDNF $+/-$, wild-type (WT) $+/+$ breeding pairs. These breeding pairs were bred to produce BDNF $-/-,+/+$ pups. Mice were genotyped by PCR $\left(94^{\circ} \mathrm{C}\right.$ for $30 \mathrm{sec}, 59^{\circ} \mathrm{C}$ for $15 \mathrm{sec}$, and $72^{\circ} \mathrm{C}$ for 30 $\mathrm{sec}$ ) using DNA obtained from tail clippings. BDNF primer sequences are GGCGCCGAACCCTCATAGACAT, GACACTTTTGAGCACGTCATCGAAG, and CGCCTTCTTGACGAGTTCTTCTG.

Tissue preparation. BDNF $-/-$ and WT pups destined for immunohistochemistry were taken at postnatal day 0.5 (P0.5) and decapitated. Incisions were made from the front of the cranium to the base of the skull. The heads were then placed in either $4 \%$ paraformaldehyde (PFA) in $0.1 \mathrm{M}$ PBS, $\mathrm{pH}$ 7.4, or Bouins' fixative overnight. For cryosectioning, tissues were then washed three times in PBS for $1 \mathrm{hr}$ each, cryoprotected by incubating overnight with consecutive concentrations of sucrose (10 and $20 \%$ ) in PBS, frozen in optimal cutting temperature compound, and stored at $-70^{\circ} \mathrm{C}$ until cryostat sectioning at $-20^{\circ} \mathrm{C}$. For paraffin sections, tissue was washed as described above, dehydrated to $75 \%$ ethanol, and stored at $-20^{\circ} \mathrm{C}$ until it was sent out for commercial preparation of sections.

Primary culture of ORNs. Primary olfactory neurons were prepared from neonatal rats as described previously (Ronnett et al., 1991) with few modifications. The tissue cultured was from 1- to 2-d-old WT rat pups. Cells were plated between 0.4 and $0.8 \times 10^{-6}$ cells $/ \mathrm{cm}^{2}$ in MEM-D-Val (Invitrogen, Grand Island, NY) supplemented with 15\% dialyzed fetal bovine serum (dFBS) (Invitrogen) without the addition of cytosine arabinoside or NGF. At $24 \mathrm{hr}$ after plating, medium was changed to $0.5 \%$ dFBS $+/-$ treatments. BDNF was used at a final concentration of 50 $\mathrm{ng} / \mathrm{ml}, \mathrm{NGF}$ at $25 \mathrm{ng} / \mathrm{ml}$, and CNP at $50 \mathrm{~nm}$ prepared from a $10,000 \times$ stock diluted in MEM-D-Val without supplements. The mitogenactivated protein kinase (MAPK)/extracellular signal-regulated kinase (ERK) kinase (MEK) inhibitor PD987059 was used at a final concentration of $50 \mu \mathrm{M}$ diluted from a $1000 \times$ stock solution prepared in DMSO. Cycloheximide (CHX) was used at a final concentration of $15 \mu \mathrm{g} / \mathrm{ml}$ diluted from a $100 \times$ stock prepared in water. Cells were harvested for immunochemistry as described below.

Immunohistochemistry. Paraffin sections were cleared of paraffin by immersion in xylene and rehydrated through an ethanol series $(100,95 \times$ $2,70,50 \%$ ethanol/water); cryosections were baked overnight at $37-42^{\circ} \mathrm{C}$ before processing for immunohistochemistry. Immunohistochemistry was performed according to the Vectastain Elite avidin-biotin complex $(\mathrm{ABC})$ procedure (Vector Laboratories, Burlingame, CA). Briefly, the sections were rinsed in PBS, permeabilized in $0.1 \%$ PBS/Triton X-100 (PBST), blocked in $4 \%$ normal serum $/ 1 \%$ BSA, and incubated with diluted antiserum at $4^{\circ} \mathrm{C}$ overnight. The slides were rinsed in PBS and then incubated in biotinylated secondary antibody for $30 \mathrm{~min}$, followed by the $\mathrm{ABC}$ for $30 \mathrm{~min}$. The peroxidase reaction was catalyzed using 3,3'-diaminobenzidine tetrahydrochloride (DAB) and hydrogen peroxide as substrates. Cryosections were rinsed in PBS and coverslipped in aqueous mounting medium. Paraffin sections were dehydrated, cleared in xylene, and coverslipped in Permount (Fisher Scientific, Fair Lawn, NJ). Slides were viewed using a Zeiss (Thornwood, NY) Axiovert microscope, and the images were captured digitally (Diagnostic Instruments, Sterling Heights, MI).

Primary antibodies against the following antigens were diluted in PBS as follows: neuron-specific tubulin (NST) (Babco, Richmond, CA), 1:1000; olfactory marker protein (OMP) (gift from Frank Margolis, University of Maryland School of Medicine, Baltimore, MD), 1:5000; and nestin (PharMingen, San Diego, CA), 1:500. Antibodies against Ki67 (Immunotech, Marseilles, France) were diluted 1:50 in high-salt 0.25\% PBST. For staining of olfactory neuronal transcription factor Olf-1 or $\mathrm{O} / \mathrm{E}-1$, GC-B, and CNP, a modified staining protocol, as described by Suzuki et al. (2000), was used to increase accessibility of antigen to antibody. Antibodies to O/E-1 (gift from R. Reed, Johns Hopkins University School of Medicine, Baltimore, MD), GC-B (a gift from K. Palczewski, University of Washington, Seattle, WA), and CNP (Peninsula Laboratories, Belmont, CA) were diluted 1:200, 1:500, and 1:7500, respectively, in $0.3 \%$ PBST. All of these antibodies are available commercially or have been characterized previously for their specificity against their target antigens (Chinkers et al., 1989; Chinkers and Garbers, 1991).

Cell counts on immunostained tissue were performed on serial sections from various regions throughout the sinus cavity. For O/E-1 cell counting (and all cell counting analyses), all immunopositive cells present in an entire coronal section were counted to avoid any bias in results that might be generated by counting only certain regions of the olfactory epithelium. Sections from null mice and their WT littermates were matched for both size and depth within the olfactory region. Staining and cell counting were performed on 6-10 sections per animal, using two to three animals per genotype. Values are reported as either the total mean \pm SEM of each genotype or the mean \pm SEM per $40 \times$ field of each genotype. Statistical significance was analyzed by Student's $t$ test using the Instat2 statistical analysis program (GraphPad Software Inc., San Diego, CA).

Immunocytochemistry. Cells from primary ORN culture were harvested at various times after treatment with neurotrophic factors and CNP. For harvesting, they were rinsed briefly with PBS, air-dried for 15-20 min, and fixed with Fixdenate (Roche Molecular Biochemicals, Indianapolis, IN) for $30 \mathrm{~min}$ at room temperature. After fixation, samples were washed with PBS and stored at $-20^{\circ} \mathrm{C}$ until use. For immunostaining, cells were washed in PBS, blocked in $4 \%$ normal serum $/ 3 \%$ BSA/PBS for $1 \mathrm{hr}$, and exposed to diluted $1^{\circ}$ antibody at appropriate concentrations ( $\alpha$-NST, 1:1000; $\alpha$-OMP, 1:7500; $\alpha$-Ki67, 1:500) in block solution overnight at $4^{\circ} \mathrm{C}$. Cells were washed the following day with PBS, treated with $1 \% \mathrm{H}_{2} \mathrm{O}_{2} / \mathrm{PBS}$ for 20 min, blocked with $0.5 \%$ BSA/PBS for $20 \mathrm{~min}$, and incubated with biotinylated $2^{\circ}$ antibody for $1 \mathrm{hr}$ at room temperature. Slides then went through a second blocking step followed by incubation with $\mathrm{ABC}$ for $90 \mathrm{~min}$ at room temperature. Detection was accomplished using a 3-amino, 9-ethyl-carbazole (AEC) peroxidase chromagen kit (Biomeda, Foster City, CA).

For cell counts of primary cultured ORNs, three rows of five $40 \times$ fields 
spaced evenly over the area of the slide were counted for each well of treatment. Values are reported as the mean \pm SEM per $40 \times$ field per treatment. In some cases data have been normalized to WT values to allow comparison of multiple experiments that differed slightly in starting cell density. Cells counts were performed on two wells per treatment from triplicate experiments. Statistical significance was determined by ANOVA of all treatments followed when applicable by Student's $t$ test comparisons of individual treatments using the Instat 2 statistical analysis program.

3'-terminal deoxynucleotidyl transferase-mediated biotinylated UTP nick end labeling and NST/3'-terminal deoxynucleotidyl transferase-mediated biotinylated UTP nick end double labeling. Paraffin sections were cleared of paraffin by immersion in xylene and rehydrated through an ethanol series $(100,95 \times 2,70,50 \%$ ethanol/water); cryosections were baked overnight at $37-42^{\circ} \mathrm{C}$ before processing for terminal deoxynucleotidyl transferase (TdT)-mediated biotinylated UTP nick end labeling (TUNEL). Sections were then incubated in $0.1 \mathrm{M}$ Tris-HCl, $\mathrm{pH} 8.0$, for $10 \mathrm{~min}$, followed by proteinase $\mathrm{K}$ treatment $(5 \mu \mathrm{g} / \mathrm{ml}) / 0.1 \mathrm{M}$ Tris, $0.5 \mathrm{M}$

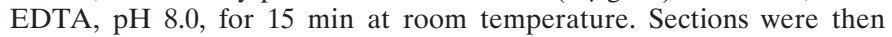
washed four times for 3-5 min in Tris- $\mathrm{HCl}, \mathrm{pH} 8.0$, and positive control sections were treated with10 U/ml RNase-free DNase RQ1 dissolved in $30 \mathrm{~mm}$ Tris-HCl, pH 7.2, $140 \mathrm{~mm} \mathrm{Na}$ cacodylate, $4 \mathrm{~mm} \mathrm{MgCl}_{2}$, and 0.1 mM DTT. All sections were then washed and treated with $1 \% \mathrm{H}_{2} \mathrm{O}_{2}$ / $\mathrm{MeOH}$ for $5 \mathrm{~min}$ at room temperature. Sections were then washed in Tris- $\mathrm{HCl}, \mathrm{pH} 7.2$, and preincubated in TdT buffer $(30 \mathrm{~mm}$ Tris- $\mathrm{HCl}, \mathrm{pH}$ $7.2,140 \mathrm{~mm} \mathrm{Na}$ cacodylate, and $1 \mathrm{~mm} \mathrm{CoCl}_{2}$ ) for $10 \mathrm{~min}$ at room temperature. Labeling was performed by the addition of TdT enzyme (200-250 U/ml; Sigma, St. Louis, MO) and biotin-16-dUTP (1:100 $1 \mathrm{~mm}$ stock) to TdT buffer and incubation of sections in this solution for $3 \mathrm{hr}$ at $37^{\circ} \mathrm{C}$. A negative control section was included by incubation in TdT buffer containing the biotin-16-dUTP label but no enzyme. After labeling, sections were washed in Tris- $\mathrm{HCl}, \mathrm{pH} 7.2$, and then blocked in $2 \%$ $\mathrm{BSA} / \mathrm{PBS}$ for $30 \mathrm{~min}$ at room temperature. Detection of biotin-16-dUTP labeling was performed by incubating sections in Vectastain Elite avidinbiotin reagents for $1 \mathrm{hr}$ at room temperature. After washing, $\mathrm{NiCl}_{2}$ enhanced DAB was used for chromagen development.

For NST/TUNEL double labeling of primary culture slides, NST staining through the addition of the primary anti-NST antibody was followed as described above. The following day a modified immunocytochemistry protocol was followed, which included treatment of the cells with $3 \% \mathrm{H}_{2} \mathrm{O}_{2} / \mathrm{PBS}$ for 5 min after the initial wash step and elimination of the second block step before exposure to the ABC. NST staining was visualized using AEC chromagen (Vector Laboratories). After NST labeling, the cells were washed in DEPC $\mathrm{H}_{2} \mathrm{O}$, pretreated with TdT buffer, and labeled with biotin-16-dUTP as described above, except that labeling was performed for only $1 \mathrm{hr}$ at $37^{\circ} \mathrm{C}$. After labeling, cells were washed twice with $2 \times$ SSC and once with PBS and then blocked with $3 \%$ normal horse serum (NHS) for $30 \mathrm{~min}$ at room temperature. Detection of biotin-16-dUTP labeling was accomplished by incubating sections in Vectastain Elite $\mathrm{ABC}$ reagents for $1 \mathrm{hr}$ at room temperature, followed by washing and chromagen development in an $\mathrm{NiCl}_{2}$-enhanced $\mathrm{DAB}$ solution. Cell counts and statistics were performed as described above; however, results are reported as the percentage of NST-positive cells that are also TUNEL-positive per $40 \times$ field.

Bromodeoxyuridine labeling of embryonic tissue and bromodeoxyuridine/ NST double labeling. Bromodeoxyuridine (BrdU) for injection into E17 pregnant mice was prepared by dissolving $4 \mathrm{mg}$ of BrdU (Roche Molecular Biochemicals, Indianapolis, IN) in $1 \mathrm{ml}$ of PBS at $37^{\circ} \mathrm{C}$ for $15 \mathrm{~min}$. The entire solution was then sterile filtered and injected intraperitoneally into the pregnant female. At $24 \mathrm{hr}$ after injection, embryonic pups were harvested as described above for neonates, fixed in $4 \%$ PFA, and prepared for cryosectioning.

After baking cryosections overnight at $37-42^{\circ} \mathrm{C}$, BrdU-labeled cells were detected as follows. Sections were washed in PBS and treated with $3 \% \mathrm{H}_{2} \mathrm{O}_{2} / 10 \% \mathrm{MeOH} / \mathrm{PBS}$ for $30 \mathrm{~min}$ at room temperature. This was followed by washing and treatment with pepsin $(0.2 \mathrm{mg} / \mathrm{ml})$ in $0.01 \mathrm{~N}$ $\mathrm{HCl} / \mathrm{PBS}$ for $20 \mathrm{~min}$ at room temperature. DNA was then denatured in a $2 \mathrm{~N} \mathrm{HCl}$ bath for $45 \mathrm{~min}$ at room temperature followed by neutralization of the acid in $0.1 \mathrm{M}$ sodium borate, $\mathrm{pH} 8.5$, for $10 \mathrm{~min}$ at room temperature.

After subsequent washing, tissue was blocked in blocking solution (100 $\mu \mathrm{l}$ of NHS from Vectastain Elite $\mathrm{kit} / 3.3 \mathrm{ml}$ of PBS) for $30 \mathrm{~min}$ at room temperature and then incubated in mouse anti-BrdU (Roche Molecular Biochemicals) 1:50/blocking solution overnight at $4^{\circ} \mathrm{C}$. The following day slides were warmed at room temperature for $45 \mathrm{~min}$, washed in PBS, and treated with biotinylated anti-mouse $(100 \mu \mathrm{l} / 5 \mathrm{ml} \mathrm{PBS})$ for $1 \mathrm{hr}$ at room temperature. Sections were then incubated in Vectastain Elite ABC reagents for $1 \mathrm{hr}$ at room temperature, followed by washing and chromagen development in an $\mathrm{NiCl}_{2}$-enhanced DAB solution. Cell counts were performed as described previously.

For BrdU/NST double labeling of primary cell cultures, BrdU reagent (Roche BrdU labeling kit; Roche Molecular Biochemicals) was diluted 1:1000 in culture medium and added to cells with appropriate treatments for various lengths of time. Cells were then harvested in Fixdenate as described above. Next, cells were washed in PBS and incubated with mouse anti-BrdU (Becton Dickinson, San Jose, CA) diluted 1:100/0.1\% BSA/PBS for $30 \mathrm{~min}$ at $37^{\circ} \mathrm{C}$. This was followed by washing in PBS and incubation with anti-mouse Ig (Fab fragment)-alkaline phosphatase (Roche Molecular Biochemicals) for $30 \mathrm{~min}$ at $37^{\circ} \mathrm{C}$. Visualization was performed with nitroblue tetrazolium/X-phosphate in detection buffer (100 mM Tris- $\mathrm{HCl}, 100 \mathrm{~mm} \mathrm{NaCl}$, and $50 \mathrm{mM} \mathrm{MgCl}_{2}, \mathrm{pH} 9.5$ ) for $20 \mathrm{~min}$ at room temperature in the dark. After BrdU detection, NST immunostaining was performed as described previously for TUNEL/NST double labeling. Cell counts and statistics were performed as described above; however, results are reported as the percentage of NST-positive cells that are also BrdU-positive per $40 \times$ field.

cGMP determinations. cGMP radioimmunoassays were performed as described previously (Ronnett et al., 1993; Jaworsky et al., 1995) with modifications. Incubations were quenched with $6 \%(\mathrm{w} / \mathrm{v}) \mathrm{TCA}$. The quenched samples were collected on ice and spun for $5 \mathrm{~min}$ in a microfuge at $4^{\circ} \mathrm{C}$. The supernatant was collected and ether extracted four times with anhydrous ether to remove TCA. cGMP was assayed with the Amersham Biosciences (Arlington Heights, IL) ${ }^{125}$ I-labeled cGMP assay system and acetylation method. Values were normalized to the level of cGMP at zero time, just before treatment with CNP.

Western blot analysis. Total homogenates of primary cultures of rat ORNs were solubilized in boiling sample buffer (100 mM Tris-HCl, $2 \%$ SDS, and $10 \% \beta$-mercaptoethanol and $20 \%$ glycerol, $\mathrm{pH} 6.8$ ) and subjected to SDS-PAGE on a $4-15 \%$ gel (Laemmli, 1970). For blotting, polyvinylidene difluoride membrane (BA-S $83 ; 0.2 \mathrm{~mm}$ ) was saturated with transfer buffer containing $25 \mathrm{~mm}$ Tris- $\mathrm{HCl}, \mathrm{pH}$ 8.3, $192 \mathrm{~mm}$ glycine, and $20 \%$ methyl alcohol. The separated proteins were transferred onto the membrane at $140 \mathrm{~mA}$ for $90 \mathrm{~min}$. After neutralization in Trisbuffered saline, $\mathrm{pH} 7.4$, plus $0.1 \%$ Tween 20 (TBST), the membrane was blocked for $2 \mathrm{hr}$ in $1 \%$ nonfat dry milk in PBS at $20^{\circ} \mathrm{C}$. The blocked membrane was washed twice in PBS, incubated in primary antibody, and diluted in $3 \%$ protease-free BSA-TBST overnight at $4^{\circ} \mathrm{C}$. The membrane was washed three times in $0.5 \%$ nonfat dry milk TBST and was then incubated with secondary antibody (HRP-conjugated antibody diluted in $3 \%$ nonfat dry milk-TBST for $1 \mathrm{hr}$ at $20^{\circ} \mathrm{C}$ ). The membrane was washed twice in $0.5 \%$ nonfat dry milk-TBST and rinsed twice in $0.2 \%$ TweenTBST. The membrane was incubated in chemiluminescence substrate for $5 \mathrm{~min}$ at $20^{\circ} \mathrm{C}$ and exposed to film. Anti-phospho-ERK1/2 and antiERK1/2 were purchased from New England Biolabs (Beverly, MA), and anti-proliferating cell nuclear antigen (PCNA) was purchased from Santa Cruz Biotechnology (Santa Cruz, CA). Anti-phospho-ERK and antiERK antibodies were used at a dilution of 1:1000. Anti-PCNA was used at a dilution of 1:500.

\section{RESULTS}

\section{BDNF regulates the proliferation and survival of olfactory receptor neuronal precursors in vivo}

Identification of factors that mediate the switch from proliferation to differentiation required that we first characterize candidate factors that regulate proliferation. The localization of BDNF and Trk B to basal cells and immature neurons in the olfactory epithelium suggests that BDNF might influence olfactory neurogenesis (Roskams et al., 1996; Buckland and Cunningham, 1999). To investigate this, mice with targeted deletion of the gene for BDNF were studied (Liebl et al., 1997). Immunohistochemistry of developmental markers expressed in ORNs was performed on cryosections of olfactory epithelium from BDNF null mice and WT littermates.

To evaluate the consequences of the absence of BDNF on the ORN population, immunohistochemistry was preformed using stage-specific markers. Neuronal daughter cells (still capable of 


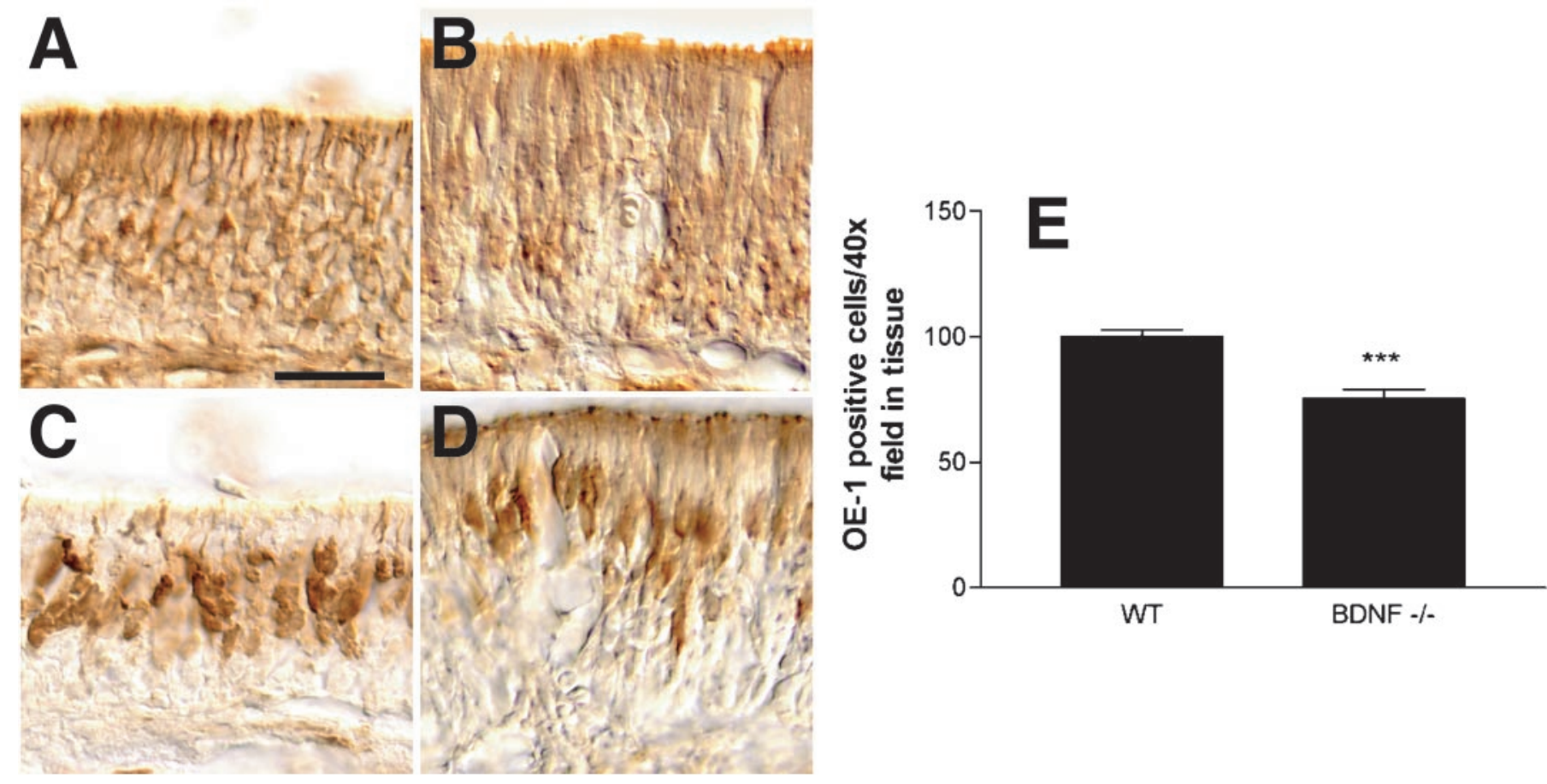

Figure 1. BDNF knock-out mice have a reduced number of ORNs. Cryostat sections of olfactory epithelium were immunostained with anti-NST antibody in WT $(A)$ and BDNF knock-out $(B) \mathrm{P} 0.5$ mice. Scale bar, $50 \mu \mathrm{m}$. Sections were immunostained with anti-OMP antibody in P0.5 WT $(C)$ and BDNF knock-out $(D)$ mice. Sections were immunostained with anti-O/E-1 (OE-1) antibody in WT and BDNF knock-out P0.5 mice, and the results were quantified by cell counting $(E)$. Because of the large number of positive cells per section, cell counts are reported as those present in linear regions per $40 \times$ field. NST is a cytoskeletal marker for immature and maturing neurons, OMP is a cytoplasmic marker for more mature neurons, and O/E-1 is a nuclear marker for all cells of a neuronal lineage. Staining was performed on 6-10 sections per mouse, two to four mice per genotype. Statistics were calculated by Student's $t$ test using the Instat2 statistics program; ***p $<0.0001$.

proliferation) and postproliferative immature ORNs are located basally in the epithelium and express NST; as ORNs mature, NST expression decreases (Lee and Pixley, 1994; Roskams et al., 1998). WT mice displayed NST-positive cells distributed at a level beginning slightly above the basal lamina and extending several cell layers apically (Fig. $1 A$ ). NST immunoreactivity was reduced in BDNF null mice, especially in the upper layers of the epithelium (Fig. 1B). Mature ORNs are located more apically and express OMP, a cytoplasmic protein found in mature ORNs (Margolis, 1985). WT mice display a normal distribution of OMP-expressing cells in the upper one-half of the epithelium (Fig. 1C). Despite the reduction in NST immunoreactivity in BDNF null mice, OMP-positive ORNs were still found in BDNF null mice, although they appeared to be reduced in number and their morphology was abnormal (Fig. 1D). This elongated morphology may be the result of decreased packing of neurons, as we have seen this in other genotypes that have reduced numbers of ORNs in the olfactory epithelium (Hansel et al., 2001b). Decreased packing of neurons may also be responsible for the increased thickness of the OE in BDNF null animals. Collectively, these observations indicate that BDNF null mice possess fewer immature olfactory neurons, but that ORNs can still mature to express OMP in the absence of BDNF. These results suggested that BDNF may influence olfactory neurogenesis or the survival of ORN precursors.

$\mathrm{O} / \mathrm{E}-1$, a transcription factor expressed in cells of the olfactory neuronal lineage (Wang and Reed, 1993), was used to quantify the number of ORNs and their precursors (Fig. 1E). Sections from WT and BDNF null mice used for this analysis were matched for both size and depth within the nasal cavity. As reported previously, O/E-1 immunoreactivity was observed throughout the neuronal layers of the epithelium in WT mice (Hansel et al., 2001b). BDNF null mice displayed a consistent decrease in the number of O/E-1-positive cells (Fig. 1E) $(p<$ $0.0001)$. These data suggest that BDNF deficiency results in a decrease in the number of ORNs in the epithelium. This decrease in $\mathrm{O} / \mathrm{E}-1$-positive cells in BDNF null mice could represent decreased proliferation, increased apoptosis, a combination of these processes, or an effect on $\mathrm{O} / \mathrm{E}-1$ expression.

Fragmentation of nuclear DNA is a marker of apoptosis in many cell types (Holcomb et al., 1995). To determine whether the reduction in ORNs in the BDNF null mice is attributable to apoptosis, we performed TUNEL on sections of olfactory epithelium from WT and BDNF null mice. BDNF null mice showed a significant increase in the number of TUNEL-positive cells within the olfactory epithelium (Fig. $2 A)(p<0.0001)$. To determine whether this increase in cell death occurred at any specific stage in development, the numbers of TUNEL-positive cells at specific levels within the olfactory epithelium were calculated as a percentage of the total number of TUNEL-positive cells. This permits correlation between apoptosis (TUNEL positivity) and developmental stage, as defined by outward migration of neurons from the basal to the outer layer as they mature (Mackay-Sim and Chuah, 2000). For this analysis, the epithelium was divided into three regions, the lower (basal) third of the epithelium containing precursors and immature neurons, a middle third containing a mixture immature and mature neurons, and an apical or upper third containing mature neurons (Fig. 2B). There was a significant increase in the percentage of apoptotic cells (percentage of total TUNEL-positive cells) within the lower 

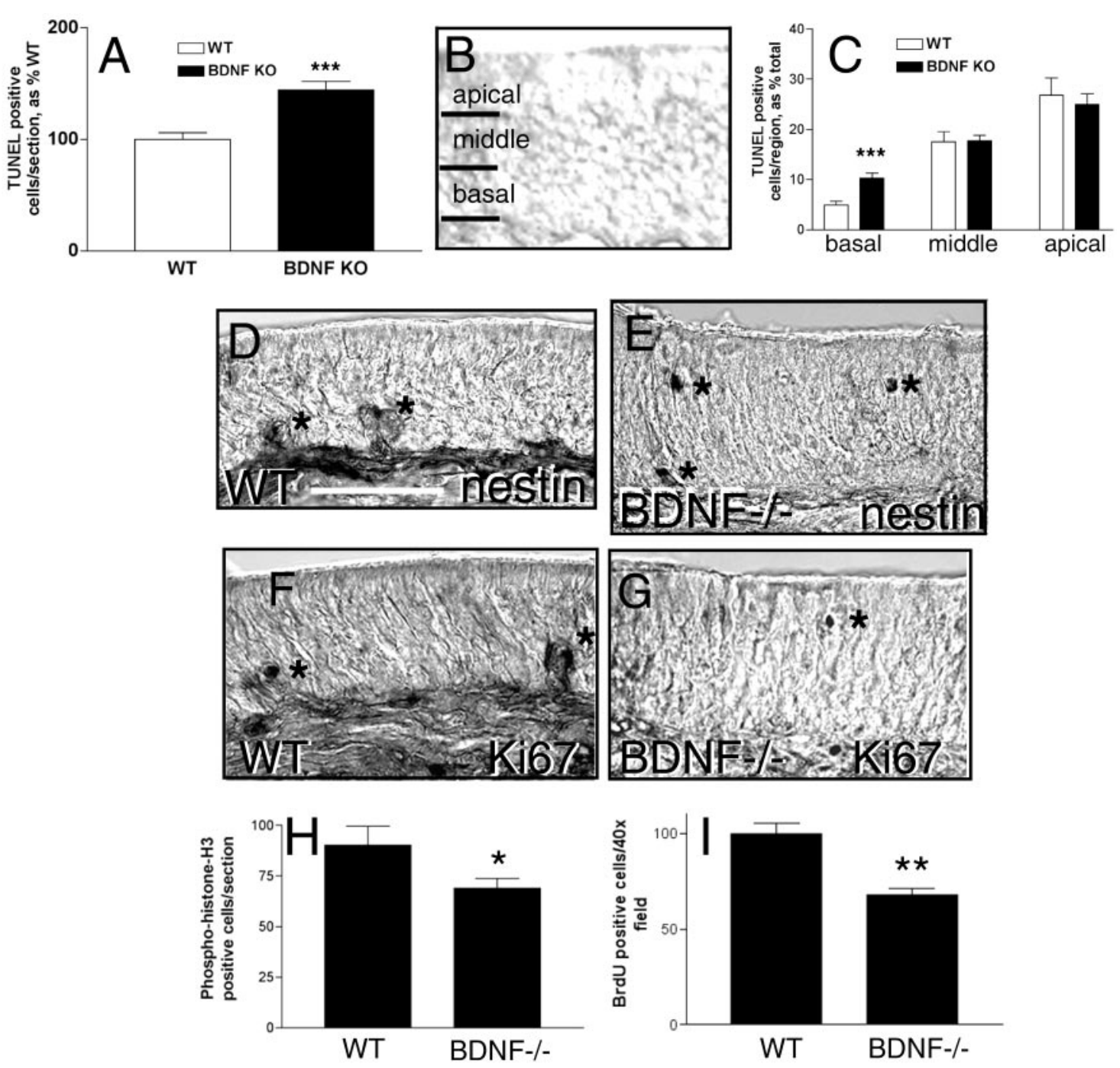

Figure 2. BDNF knock-out $(K O)$ mice demonstrate increased apoptosis and decreased proliferation within the basal cell region of the olfactory epithelium. $A$, TUNEL staining was performed on the olfactory epithelium from WT and BDNF knock-out animals and quantified across the entire epithelium. ${ }^{* * *} p<0.0001$ (direct cell counts: WT, $148 \pm 9$; BDNF null, $220 \pm 15$ TUNEL-positive cells/section). $B$, To evaluate the number of cells undergoing apoptosis at different times in the ORN life cycle, the epithelium was divided into thirds, representing the basal third containing neuronal precursors and some immature neurons, the middle third containing immature and mature neurons, and the apical or upper third containing mature neurons and sustentacular cell bodies. This schematic of the olfactory epithelium shows regional definitions that were used for TUNEL cell counting. $C$, The number of TUNEL-positive cells per region within the olfactory epithelium as defined in $B$ is presented as a percentage of the total number per section. Direct cell counts (WT, $7.3 \pm 1.1$; BDNF null, $22.6 \pm 2.2$ TUNEL-positive cells within the lower one-third of the OE per section) demonstrate that BDNF null animals show a threefold increase in the number apoptotic cells found in the basal region over WT animals. Statistics were calculated by ANOVA followed by Student's $t$ tests. $n=10-15$ sections per mouse, three mice per genotype. ${ }^{* *} p<0.0001$. Nestin and Ki67 immunostaining were performed on the olfactory epithelium from P0.5 WT $(D, F)$ and BDNF knock-out $(E, G)$ mice to confirm the results of TUNEL that suggested a decrease in the population of neuronal precursors and immature neurons in BDNF knock-out animals. Scale bar, $50 \mathrm{~mm}$. Nestin- and Ki67-positive cells are indicated by asterisks. Nestin is a marker for neuroepithelial stem cells. Ki67 is a marker for non-Go cells. Both nestin and Ki67 staining were reduced in BDNF knock-out mice. Nestin and Ki67 staining were performed on 6-10 sections per mouse, three to four mice per genotype. $H$, The total number of H3-phosphohistone-stained cells per section in P0.5 WT and BDNF knock-out mice was quantified. H3-phosphohistone is a marker for cells undergoing mitosis, and was reduced in BDNF knock-out mice. I, Timed-pregnant mice received BrdU at E17, and embryos were harvested at E18 to examine the number of cells that incorporated BrdU in the olfactory epithelium. BrdU incorporation is a marker of DNA synthesis. The number of BrdU-positive cells per $40 \times$ field in $24 \mathrm{hr}$ labeled E18 WT and BDNF knock-out mice was quantified. Cell counts were performed on $6-10$ sections per mouse, two to three mice per genotype. Statistics were calculated by ANOVA followed by Student's $t$ tests; ${ }^{*} p<0.05 ; * *<0.001$.

(basal) region in BDNF null mice when compared with WT mice (Fig. $2 C)(p<0.0001)$. When normalized for differences in the total number of apoptotic cells per genotype, this difference represents a threefold increase in apoptosis in BDNF null mice specifically within the basal one-third of the epithelium. No other region of the olfactory epithelium showed a significant difference in the percentage of TUNEL-positive cells between the two genotypes. If all percentages are normalized for differences in the total number of apoptotic cells per genotype (165\% in BDNF null mice vs $100 \%$ in WT mice), there is very good agreement with data obtained from counting total apoptotic cells in null and WT animals directly (144\% in BDNF null mice vs $100 \%$ in WT mice). This suggests that BDNF specifically affects the survival of ORN precursors and not the survival of mature neurons.

Other developmentally expressed markers were used to confirm these findings. Nestin is a marker for neuroepithelial stem 
cells (Zimmerman et al., 1994); however, others have suggested that it identifies different classes of cells (Tohyama et al., 1992; Zimmerman et al., 1994; Osada et al., 1995). In the olfactory epithelium, nestin appeared to identify neuronal precursor cells, in addition to basal cells, within the lower region of the epithelium. Immunohistochemistry using anti-nestin antibodies consistently identified fewer cells within the olfactory epithelium of the BDNF null mice compared with littermate WT controls (Fig. $2 D, E)$. Interestingly, nestin antibodies identified several layers of basally positioned cells and small clusters of apically extending cells in the WT epithelium, whereas the few nestin-positive cells that remained in the BDNF null mice were found as single cells distributed at all layers of the epithelium (Fig. 2D,E, asterisks). These results confirm the decrease in neuronal precursor numbers that would be expected based on results of TUNEL analysis showing increased apoptosis in the basal region in BDNF null mice.

The increased apoptosis of ORN precursors seen in the BDNF null phenotype suggests two possible effects on proliferation. One would be a decrease in proliferation, based on a decrease in the number precursor cells available to proliferate. In many cases, however, a compensatory upregulation of olfactory neurogenesis is observed as a result of injury to the olfactory epithelium or olfactory bulb. In these cases, increases in ORN death lead to an upregulation of neuronal precursor proliferation (Kastner et al., 2000). In our case, it is possible to imagine that although the number of olfactory neuronal precursors present in BDNF null animals is reduced, those precursors still present may compensate for this reduction by undergoing additional rounds of cell division.

To evaluate the neuronal precursor population and proliferation in BDNF null mice, we performed immunohistochemistry on the olfactory epithelium from WT and null mice using antibodies to Ki67, a marker for nonquiescent cells (Fig. 2F,G) (Mahadevan et al., 1991; Ajiro et al., 1996). These results showed no compensatory increase in proliferation within the olfactory epithelium, but rather a decrease in the number of proliferating cells. Ki67 antibodies identified fewer cells within the olfactory epithelium of BDNF null mice compared with WT littermates. Within the epithelium of WT mice, immunostaining with antibodies to $\mathrm{Ki} 67$ appeared to be primarily localized to groups of cells within proliferative clusters, located slightly above the basal cell layer (Fig. $2 F$ ). No obvious changes were seen in the actual basal cell layer itself. In BDNF null mice, only single cells were visualized, again distributed throughout the epithelium (Fig. $2 G$ ). This lack of proliferative clusters suggests that individual surviving neuronal precursors are not induced to undergo increased proliferation. Based on the localization of this staining, these data also suggest that BDNF is required for the rapid proliferation of daughter cells after their migration from the basal cell layer (Mackay-Sim and Kittel, 1991), rather than for the first round of division within the basal cell layer.

Antibodies to phosphohistone H3, a marker for mitosis (M phase) (Rijzewijk et al., 1989), revealed that the differences in proliferation between WT and BDNF null mice were statistically significant (Fig. $2 H)(p<0.05)$. These results were confirmed by analysis of BrdU labeling in WT and BDNF null mice. Timedpregnant female mice received BrdU at E18, and embryos were harvested $24 \mathrm{hr}$ later (Fig. 2I). A significant reduction in the number of BrdU-labeled cells in the null animals was observed compared with WT animals $(p<0.001)$, confirming the observations obtained using the $\mathrm{H} 3$ mitosis marker. These findings
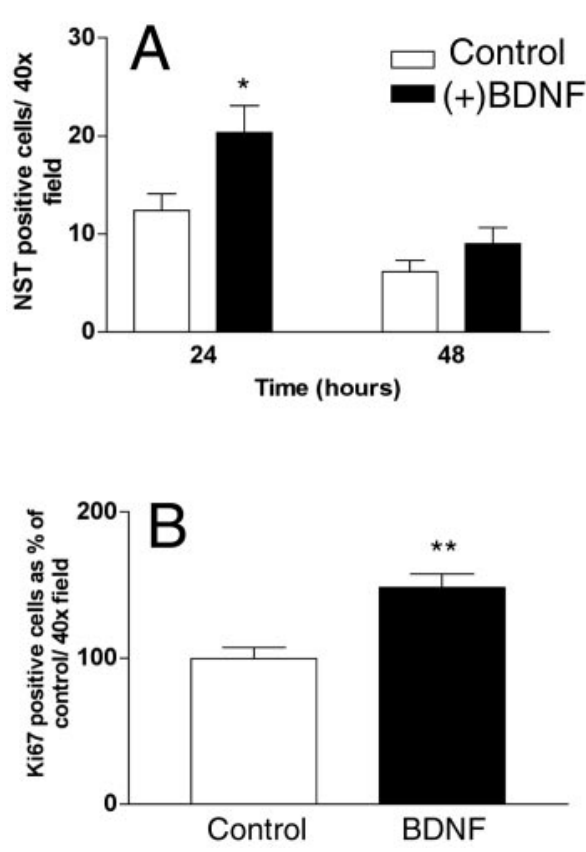

Figure 3. BDNF increases the number of NST-and Ki67-positive cells in primary cultures of olfactory epithelium in vitro. Primary cultures were prepared from P1 rat pups as described in Materials and Methods and incubated for various times in medium with or without $50 \mathrm{ng} / \mathrm{ml} \mathrm{BDNF}$. $A$, The number of NST-positive cells per $40 \times$ field in ORN culture at 24 and $48 \mathrm{hr}$ after addition of BDNF was determined. $B$, The number of Ki67-positive cells per $40 \times$ field in ORN culture from $\mathrm{P} 1$ rat pups with or without $50 \mathrm{mg} / \mathrm{ml} \mathrm{BDNF}$ at the $24 \mathrm{hr}$ time point was determined. The data were normalized to WT. Statistics were calculated by ANOVA followed by Student's $t$ tests; ${ }^{*} p<0.05$; ** $p<0.001 . n=15$ counts per well, two wells per treatment, from triplicate experiments.

demonstrate that BDNF influences the proliferation of neuronal precursors and suggest that it may be involved in supporting the survival of immature neurons within the olfactory epithelium in vivo.

\section{BDNF induces neuronal precursor proliferation in vitro}

To confirm these results and to investigate the interactions of BDNF with factors that might influence neuronal differentiation, we used primary cultures of olfactory epithelium enriched for olfactory neuronal precursors (Ronnett et al., 1991). These cultures have been used to study the roles of a number of factors that regulate olfactory neurogenesis (Hansel et al., 2001ab). ORNs in these cultures express stage-specific markers and respond to odorants (Cunningham et al., 1999; Barber et al., 2000).

When added to cell cultures containing ORN precursors, BDNF caused a dose-dependent increase in the number of NSTpositive neurons within $24 \mathrm{hr}$ after application (Fig. $3 A)(p=$ 0.02 ), confirming that BDNF influenced precursor proliferation and/or survival of immature neurons. This effect was dosedependent up to a dose of $50 \mathrm{ng} / \mathrm{ml}$ (data not shown). In addition, BDNF also caused a significant increase in the number of Ki67positive cells in culture within this same time period (Fig. $3 B$ ) $(p=0.0026)$, suggesting that at least part of the increase in ORNs seen in BDNF-treated cultures was caused by increased proliferation. Thus, BDNF influences olfactory neuronal precursor proliferation in vivo and in vitro. We therefore used BDNF as a treatment to identify factors that could specifically affect the maturation of proliferating ORN precursors. 


\section{GC-B}

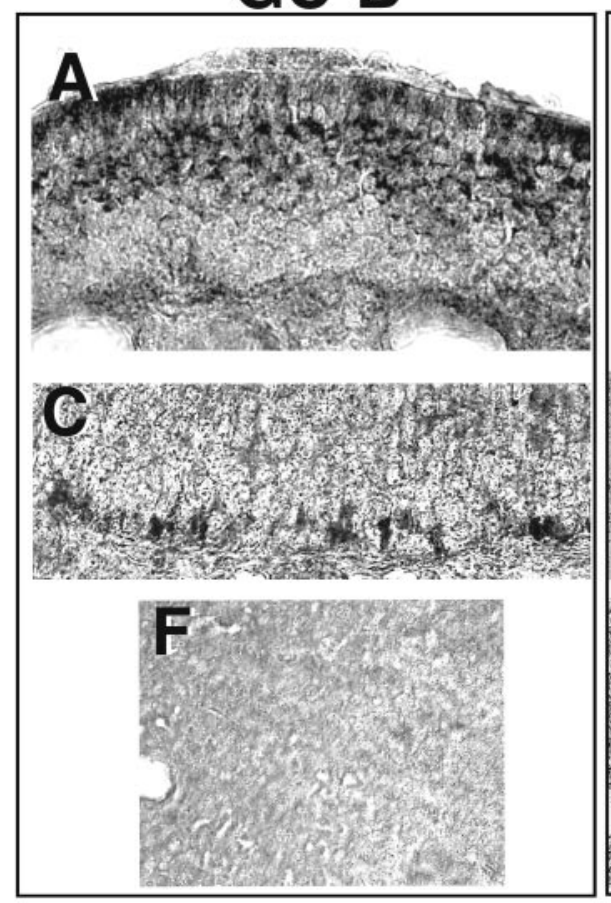

CNP

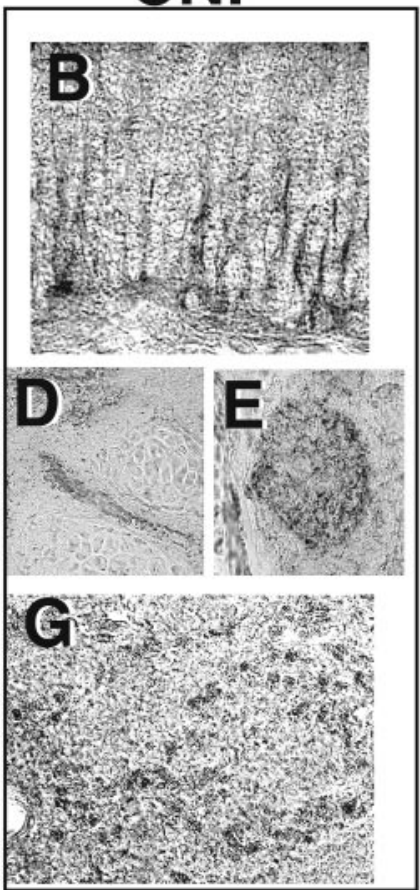

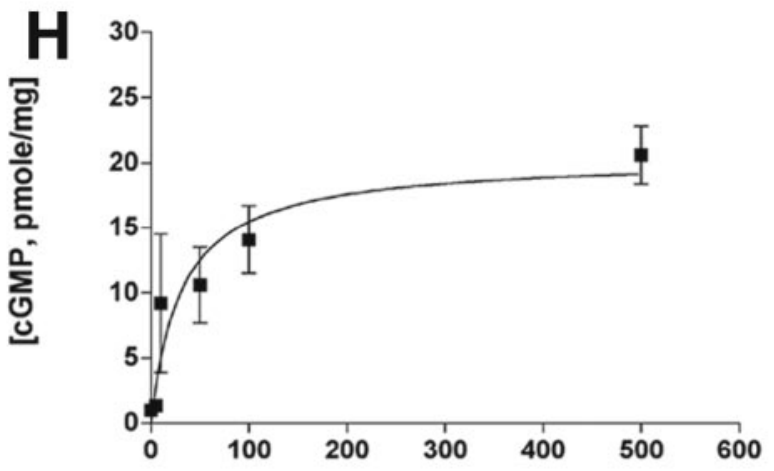

[CNP, nM]

Figure 4. GC-B and CNP are positioned to play a role in ORN development and regeneration. Cryosections of adult olfactory epithelium and bulb were immunostained for GC-B or CNP. A, C, Staining of adult rat olfactory epithelium with anti-GC-B antibody indicated that GC-B was expressed in more mature cells found in the upper layer of the epithelium $(A)$ and within cells of and migrating out of the basal cell layer $(C)$. This pattern was also seen in P1 mouse pups, although the staining was lighter and more diff use (data not shown). $F$, Immunostaining of the adult rat olfactory bulb with anti-GC-B antibody demonstrated that GC-B does not appear to be present in the bulb. B, Immunostaining of the adult rat olfactory epithelium with anti-CNP antibody showed that CNP was expressed in sustentacular cell processes and foot pads. Intense staining is also seen within axon bundles within the lamina propria $(E)$ and leading into the olfactory bulb $(D)$. Within the epithelium of P1 rat pups, CNP was present within scattered cells, both mature and immature, throughout the epithelium (data not shown). $G$, Immunostaining of the adult bulb with anti-CNP antibody demonstrated expression of CNP in periglomerular cells surrounding the glomeruli. Within the adult olfactory bulb, cells of the mitral cell layer were also densely stained (data not shown). Within P1 rat pups, staining is also seen within the forming glomeruli and within the mitral cell layer (data not shown). Staining was performed on 5-10 sections from each of two to three rats from both P1 pups and adult animals. $H$, cGMP production in response to CNP added to primary cultures of P1 rat ORNs. $n=2$ values per dose from triplicate experiments.

\section{GC-B and CNP are expressed within the olfactory system}

Immunohistochemistry was performed to localize GC-B and CNP in the olfactory epithelium, (Fig. 4). GC-B was localized to ORNs in the upper one-half of the epithelium of the adult rat, where immature and maturing neurons reside (Fig. 4A). GC-B was also expressed in stretches of cells located near the basal lamina, at the interface of the olfactory epithelium and the lamina propria, and in cells just above this interface (Fig. $4 C$ ). Staining in both distribution patterns was found within the same regions throughout the $\mathrm{OE}$. This pattern was present in $\mathrm{P} 1$ neonatal mouse and rat pups, although the staining was lighter and more diff use (data not shown). GC-B was not detected in the olfactory bulb (Fig. 4F).

CNP was expressed in both the olfactory epithelium and the olfactory bulb (Fig. 4B,D,E,G). Within the olfactory epithelium of adult rats, CNP was associated with sustentacular cells, and expression was most prominent in sustentacular cell foot processes (Fig. 4B). CNP was also associated with ORN axon bundles in the lamina propria leading into the bulb (Fig. 4D,E). In contrast to GC-B, CNP was expressed in the olfactory bulb in periglomerular cells that surround the glomeruli (Fig. $4 G$ ), and, in some cases, within the mitral cells deeper within the bulb (data not shown). The localization of CNP in the bulb confirmed a previous study (Herman et al., 1996). The expression of GC-B in ORNs located in different layers of the epithelium, and of CNP in sustentacular cells and in cells surrounding glomeruli, position CNP to act as a paracrine factor that could regulate neuronal differentiation or survival.

To demonstrate that GC-B is present and functional (capable of being activated by $\mathrm{CNP}$ ) in our primary culture system, we measured cGMP production in response to a 5 min CNP treatment (Fig. 4H). CNP caused a dose-dependent increase in cGMP with a $K_{\mathrm{m}}=31.4 \mathrm{~nm}$. The localization of GC-B and CNP in the olfactory epithelium suggested that CNP might affect growth factor-induced proliferation in ORN development, as it does in non-neuronal cells.

\section{CNP blocks BDNF-induced proliferation in ORNs in vitro}

To determine whether CNP was capable of blocking BDNFinduced proliferation, these factors were added to primary cultures individually and in combination. Extensive time courses using BrdU/NST double labeling were performed to permit analysis of the role of CNP on BDNF-induced neuronal proliferation (Fig. 5). This double labeling indicates the number of neuronal precursors that are proliferating during BrdU incorporation and are, or subsequently become, NST-positive. This group of cells is 

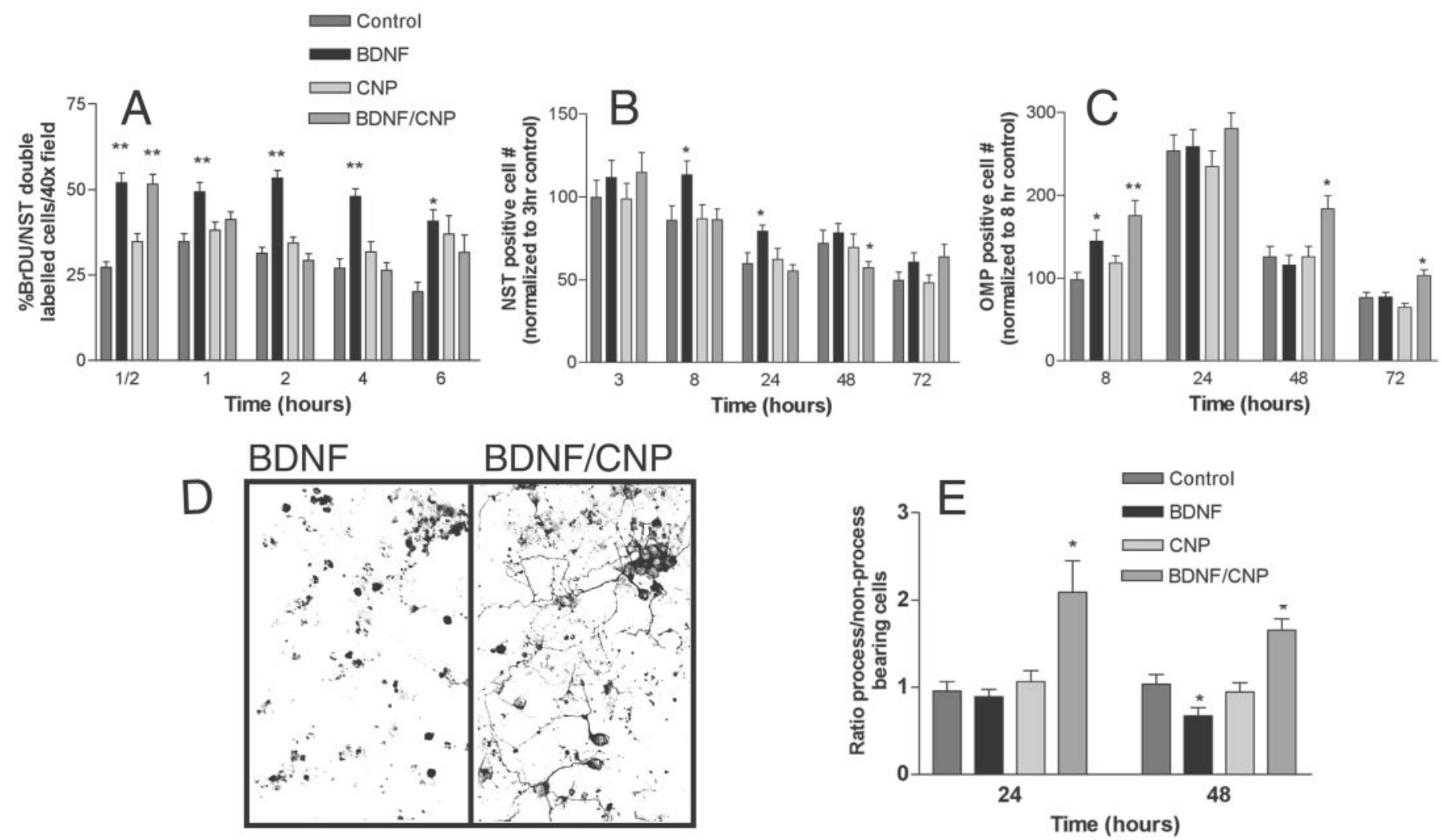

Figure 5. CNP antagonizes BDNF-induced proliferation and promotes the formation, survival, and process outgrowth of more mature neurons. Primary cultures were prepared and incubated in control medium or in medium containing BDNF alone, CNP alone, or a combination of the two as indicated. $A$, The effect of BDNF and CNP both together and separately on BrdU incorporation in NST-positive neurons over a 6 hr time course. $B$, The effect of BDNF and CNP on the number of NST-positive cells in culture over a $72 \mathrm{hr}$ time course; data have been normalized to $3 \mathrm{hr}$ control values. $C$, The effect of BDNF and CNP on the number of OMP-positive cells in culture over a $72 \mathrm{hr}$ time course; data were normalized to $8 \mathrm{hr}$ control values. In all cases, the concentration of BDNF was $50 \mathrm{ng} / \mathrm{ml}$ and the concentration of CNP was $50 \mathrm{nM}$. Statistics were calculated by ANOVA followed by Student's $t$ tests; ${ }^{*} p<0.05 ; * p<0.001 . n=8$ counts from each of two wells per treatment from triplicate experiments. $D$, Photographs of ORNs in primary culture immunostained with anti-NST in the presence of either BDNF alone or BDNF and CNP, demonstrating the differences seen in process outgrowth between the two treatments. $E$, Graph showing the number of cells displaying processes versus non-process-bearing cells in cultures treated with BDNF, CNP, or BDNF and CNP combined. $n$ represents 15 counts per well from two wells per treatment from triplicate experiments; ${ }^{*} p<0.05$.

referred to as neuronal precursors. BDNF caused a significant increase in the number of BrdU-positive neurons within 30 min of application (Fig. $5 A)(p<0.001)$. The number of proliferating cells remained high for $4 \mathrm{hr}$ but began to decrease between 4 and $6 \mathrm{hr}$. The rapid increase seen in proliferation in response to BDNF suggests that BDNF has a direct effect on proliferation itself, and that the decrease in BrdU labeling seen in vivo was not attributable entirely to increased cell death.

We subsequently wanted to determine whether CNP might inhibit proliferation and induce maturation (Fig. 5A). BDNF treatment caused a twofold increase in the number of BrdU/NSTpositive cells by $30 \mathrm{~min}(p<0.001)$, whereas CNP alone had little effect ( $p=0.03)$. In contrast, CNP, added at the same time with BDNF, completely abolished BDNF-induced proliferation by 2 $\mathrm{hr}(p<0.001)$. The fact that CNP was not able to inhibit BDNF within 30 min suggests that the mechanism used by CNP to cause this inhibition requires a kinetically longer signal transduction pathway, or perhaps even an alteration in gene expression.

The number of NST-positive cells was also analyzed to determine the fate of cells undergoing proliferation (Fig. 5B). BDNF increased the number of NST-positive cells in culture over an 8-24 hr time course, with a maximum effect at $8 \mathrm{hr}$. CNP alone had no effect on the number of NST-positive cells at any point in the time course. However, the addition of $\mathrm{CNP}$ with BDNF completely abolished the BDNF-induced increase at both the 8 and $24 \mathrm{hr}$ time points. By $48 \mathrm{hr}$, BDNF-treated cultures no longer showed an increased number of NST-positive cells over control values. CNP applied in the presence of BDNF, however, was still able to cause an additional and significant reduction in NSTpositive cells compared with controls. These data suggest that the increase in NST-positive neurons in response to BDNF is attributable, at least in part, to rapid induction of proliferation. The decrease in NST-positive cells seen in the presence of BDNF and CNP (48 hr) suggests that under these conditions proliferating neuronal precursors either do not survive or mature and lose NST immunoreactivity.

\section{CNP promotes differentiation and survival of ORNs treated with BDNF}

To investigate further the fate of proliferating NST-positive cells, OMP immunocytochemistry was performed (Fig. 5C). The time course for formation of OMP-positive cells in culture is slightly later than that for cells expressing NST, reaching a maximum between 24 and $48 \mathrm{hr}$, a time period during which BDNF loses its effectiveness in increasing the number of NST-positive cells. Treatment with either BDNF or CNP alone during this period 


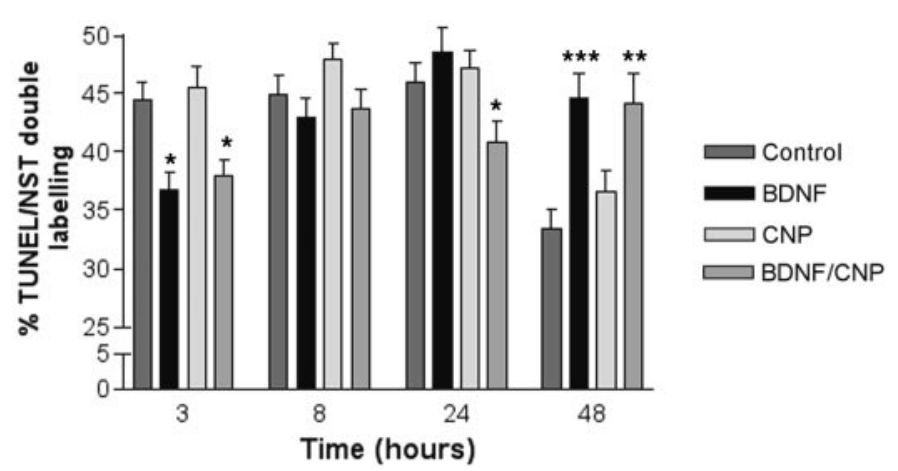

Figure 6. The effect of BDNF and CNP on apoptosis of NST-positive neurons. Primary cultures received BDNF and CNP alone or in combination over a $48 \mathrm{hr}$ time course. In all cases, the concentration of BDNF was $50 \mathrm{ng} / \mathrm{ml}$ and the concentration of CNP was $50 \mathrm{nM}$. Statistics were calculated by ANOVA followed by Student's $t$ tests; *p $<0.05$; ** $p<$ $0.001 ; * * * p<0.0001 . n=15$ counts from each of two wells per treatment from triplicate experiments.

had no effect on the number of cells expressing OMP. However, when cultures were treated with BDNF and CNP together, the number of OMP-positive neurons increased significantly by $48 \mathrm{hr}$. These data suggest that CNP not only interrupts BDNF-induced proliferation but also promotes the formation and/or survival of more mature neurons.

The above data suggest that in the presence of CNP, BDNF "primed" cells switch from a program of proliferation to differentiation. However, these results do not discriminate between increased differentiation and increased survival of older neurons. To address this question, we examined the morphology of NSTpositive cells treated with BDNF and CNP either together or separately (Fig. 5D). Two distinct NST-positive cell populations were visualized: one population consisting of densely stained round cells that displayed no process outgrowth, and another consisting of cells possessing densely stained processes of various lengths and lighter stained cell bodies (Fig. 5D). By $24 \mathrm{hr}$, cells treated with both BDNF and CNP showed a significant increase in the ratio of process-bearing versus non-process-bearing NSTpositive cells (Fig. $5 E)(p=0.004)$, although as indicated above, the total number of NST-positive cells was not increased above control values (Fig. 5E). CNP alone had no effect. After 48 hr, this value remained significantly higher than controls, whereas cultures treated with BDNF alone showed a significant decrease in the ratio of process-bearing to non-process-bearing NSTpositive cells $(p=0.016)$. These changes in morphology were clearly visible within the cultures by $48 \mathrm{hr}$ (Fig. 5D). These data indicate that CNP induces differentiation in BDNF-treated cultures, as monitored by process extension and OMP expression. These data also suggest that in the absence of additional factors, cells that have been induced by BDNF to proliferate fail to undergo further differentiation and become quiescent.

Based on our in vivo data, BDNF may not only act as a proliferation-inducing factor but may also aid in the survival of proliferating immature neurons. To investigate this possibility, we examined the effects of these factors on apoptosis using TUNEL/NST double labeling. BDNF treatment caused a significant reduction in the number of NST-positive apoptotic cells (Fig. 6) ( $p=0.0027)$ within $3 \mathrm{hr}$, confirming our in vivo TUNEL data. In contrast to its effect on BDNF-induced proliferation, CNP did not affect BDNF-induced survival at this time point. This suggests that separate signal transduction pathways are involved in the survival and proliferationinducing effects of BDNF, and confirms that BDNF has an effect on proliferation that is not attributable to increased survival of proliferating cells.

By $24 \mathrm{hr}$ in culture, BDNF no longer had an effect on survival. This result confirmed our in vivo data that suggested that BDNF affected ORN precursors early in their life cycle (Fig. 6). When CNP was added along with BDNF, however, the number of apoptotic neurons was significantly reduced by $24 \mathrm{hr}(p=0.039)$, supporting a role for CNP in the survival of older neurons. By 48 hr, both BDNF- and CNP/BDNF-treated cultures showed a significant increase in the numbers of apoptotic NST-positive neurons ( $p<0.0001, \mathrm{BDNF} ; p=0.0006, \mathrm{CNP} / \mathrm{BDNF})$. It is at this stage in culture that $\mathrm{CNP} / \mathrm{BDNF}$-treated cultures showed a significant increase in the number of OMP-positive cells (Fig. $5 C$ ); it may be that NST-positive neurons that fail to undergo further maturation at this point undergo apoptosis.

\section{NGF induces ORN precursor proliferation followed by increased apoptosis}

We wanted to determine whether CNP could also affect ORN precursor proliferation induced by other factors. Although NGF is primarily associated with differentiation, process outgrowth, and survival responses in neurons and PC12 cells, it has been shown to stimulate proliferation in some neuronal populations (Geffen and Goldstein, 1996; Anastasiadis et al., 1997; Goldstein et al., 1997; Jiang et al., 1997; Calza et al., 1998; Sieber-Blum, 1998). In the olfactory system, NGF is positioned to be involved in neurogenesis after bulbectomy. NGF expression is seen in ORNs in the upper one-half of the epithelium, where it appears to be associated with cells destined to die (Roskams et al., 1996). Within $3 \mathrm{~d}$ after bulbectomy, Trk A expression appears within basally located cells in the olfactory epithelium and remains high for up to 2 weeks (Roskams et al., 1996). These results suggest that the NGF may be released from older cells that are dying within the olfactory epithelium in response to bulbectomy as a signal for basal cells to begin proliferation.

To examine this potential role for NGF in olfactory neurogenesis, we determined the effect of NGF and CNP on neurogenesis in vitro. As with BDNF, NGF was found to induce neuronal proliferation (Fig. 7A), although over a longer time course than BDNF. No significant increase in proliferation was seen until $4 \mathrm{hr}$ $(p=0.03)$ after the addition of NGF, and proliferation remained significantly increased for at least $24 \mathrm{hr}(p=0.0001)$. To determine the fate of these proliferating precursors, NST immunostaining was performed (Fig. $7 B$ ). In contrast to results obtained with BDNF, NGF did not increase the number of NST-positive cells at any time over a 24-96 hr time course. These data indicated that NGF induced neuronal proliferation but did not lead to an increase in the number of NST-positive cells, and suggested that cells treated with NGF must have a different fate than those treated with BDNF. Several possible fates exist for these cells: quiescence in an immature state before NST expression, cell death after proliferation, or rapid maturation and a switch to OMP expression. To examine these possibilities, we performed TUNEL/NST double labeling on NGF-treated cells (Fig. 7C). Within $24 \mathrm{hr}$ after treatment with NGF, at a time when cells were undergoing NGF-induced proliferation, apoptosis was increased significantly above control values (Fig. $7 C)(p=0.002)$. 

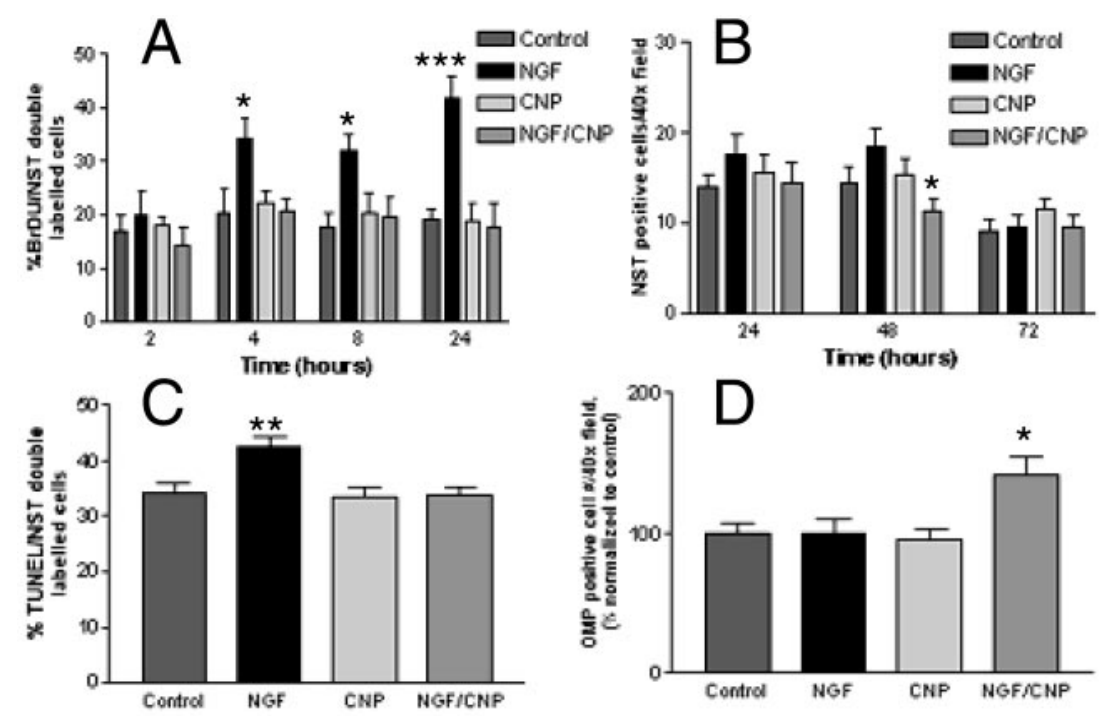

Figure 7. CNP antagonizes NGF-induced proliferation and promotes neuronal maturation and survival. Primary cultures were prepared and treated with control medium or medium containing NGF or CNP alone or in combination as specified. $A$, The effect of NGF and CNP both together and separately on BrdU incorporation in NSTpositive neurons was determined over a $24 \mathrm{hr}$ time course.

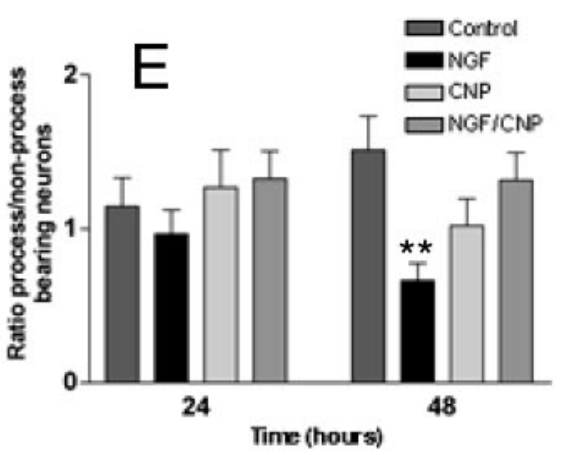
$B$, The effect of NGF and CNP on the number of NSTpositive cells in culture was measured over a $72 \mathrm{hr}$ time course. $C$, The effect of NGF and CNP on apoptosis of NST-positive neurons in culture was determined after 24 hr of treatment. $D$, The effect of NGF and CNP on the number of OMP-positive cells in culture was determined after $72 \mathrm{hr}$ of treatment; data were normalized to control values. $E$, The effects of NGF and CNP alone or in combination on process outgrowth were determined. In all cases, the concentration of NGF was $25 \mathrm{ng} / \mathrm{ml}$ and the concentration of CNP was $50 \mathrm{~nm}$. Statistics were calculated by ANOVA followed by Student's $t$ tests; ${ }^{*} p<0.05$; ${ }^{* *} p<0.001 ; * * * p<0.0001 . n=15$ counts per well for two wells per treatment from triplicate experiments.

\section{CNP inhibits NGF-induced neuronal proliferation in vitro and rescues cells from apoptosis}

When CNP was added to NGF-treated cells, CNP was able to completely abolish the NGF-induced increase in proliferation (Fig. 7A). CNP also completely inhibited the increase in apoptosis of NST-positive cells in response to NGF (Fig. 7C). This suggests that in the absence of additional factors, many of the cells induced by NGF to proliferate undergo apoptosis, and that CNP is able to both inhibit this proliferation and save NGF-treated cells from subsequent apoptosis.

Interestingly, when the effect of CNP on the total number of NST-positive cells in NGF-treated cultures was examined, a significant decrease in the number of NST-positive cells was evident within $48 \mathrm{hr}$ (Fig. 7B) $(p=0.0031)$. This time point corresponds to the time point at which CNP showed the maximal ability to induce differentiation of BDNF-treated neuronal precursors and suggested that in the absence of their death, these cells continue to the next level of ORN maturity.

\section{CNP also promotes the differentiation of NGF- treated cells}

To confirm that CNP also induced differentiation/maturation of NGF-treated neurons, we examined the effects of CNP and NGF on OMP staining in culture after $72 \mathrm{hr}$ of treatment (Fig. $7 D$ ). Addition of CNP to NGF-treated cultures resulted in a significant increase in the number of OMP-positive neurons at this time (Fig. $7 D)(p=0.015)$.

Analysis of the ratio of process/non-process-bearing NSTpositive cells (Fig. 7E) showed that NGF, like BDNF, caused a substantial decrease in the number of process-bearing cells within $48 \mathrm{hr}$ after treatment. However, unlike cells treated with BDNF/CNP, NGF/CNP-treated cells did not show a significant increase in process outgrowth but did return to control values, as would be expected if CNP acts on the maturation of ORN precursors saved from cell death. These results confirm that CNP can act on cells pretreated with at least two different growth factors to influence maturation. It also suggests that, based on differing time courses of action, fates of treated cells, and localization of receptors, NGF and BDNF may act on cells at two different developmental stages, both of which are sensitive to CNP.

\section{The effects of CNP are mediated by cGMP}

We investigated the specificity of the effect of CNP on BDNFtreated cells by using atrial A-type and B-type natriuretic peptides (ANPs and BNPs, respectively), as well the full-length CNP peptide (C53), because a shorter peptide is generally used for most experiments (C22) (Sudoh et al., 1990). As with C22, C53 alone had no effect on ORN precursors, but $\mathrm{C} 53$ reproduced the effect of $\mathrm{C} 22$ in inhibiting BDNF-induced proliferation (Fig. $8 A$ ). Neither ANP nor BNP was able to mimic the effect of C22 and C53 (data not shown). To confirm that the effect was caused by an increase in cGMP, we also analyzed the effect of 8-bromo-cGMP on BDNF-induced proliferation. As with CNP, 8-bromocGMP had little effect alone. At a concentration of $1 \mathrm{nM}$, 8-bromo-cGMP completely inhibited BDNF-induced proliferation (Fig. $8 B$ ). 

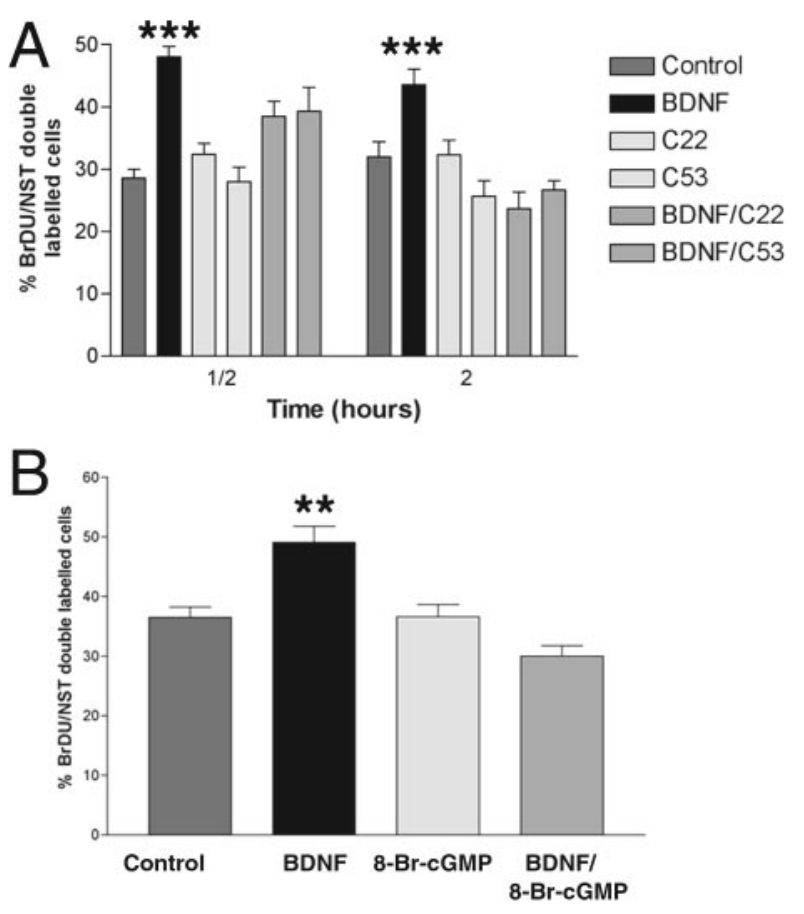

Figure 8. The effect of CNP on BDNF-primed cultures is specific and is mimicked by 8 -bromo-cGMP. Primary cultures were prepared and treated with control medium or medium containing BDNF, CNP, C22, or C53 alone or in combination as indicated. $A$, Comparison of the effect of the truncated $\mathrm{C} 22$ peptide with full-length CNP (C53), both alone and in the presence of BDNF, on BrdU incorporation into NST-positive neurons. As can be seen, the effects of the two peptides alone and with BDNF are almost identical at both the $30 \mathrm{~min}$ and $2 \mathrm{hr}$ time points. Neither ANP nor BNP mimicked these effects (data not shown). BDNF statistical significance applies to control, $\mathrm{BDNF} / \mathrm{C} 22$, and $\mathrm{BDNF} / \mathrm{C} 53$ results at both time points; *** $p<0.0001$. B, The effect of 8-bromo-cGMP $(8-B r-c G M P)$ on BrdU incorporation into NST-positive neurons with and without BDNF. 8-bromo-cGMP was used at a concentration of $1 \mathrm{~nm}$. For each graph, $n$ represents 15 counts per well, two wells per treatment from triplicate experiments. Statistics were calculated by ANOVA followed by Student's $t$ tests; **p $<0.001$.

\section{CNP requires protein synthesis to inhibit BDNF-induced proliferation}

CNP may exert its effect by several mechanisms. It may directly interfere with the BDNF-induced signal transduction pathway, or it may inhibit proliferation through an independent pathway to alter gene expression. To address whether or not CNP requires gene expression to block BDNF-induced proliferation, we examined the effects of $\mathrm{CHX}$ on this process (Fig. 9). Based on the time course of action of BDNF and CNP, we hypothesized that BDNF-induced proliferation would not be inhibited by $\mathrm{CHX}$, whereas the ability of CNP to block BDNF action would be inhibited. BDNF-induced proliferation was entirely unaffected by $\mathrm{CHX}$, whereas the ability of CNP to inhibit this proliferation was completely blocked (Fig. 9A). CHX blocked the effect of CNP when $\mathrm{BDNF} / \mathrm{CNP}$ and $\mathrm{CHX}$ were added at the same time (Fig. $9 A-C$ ) or when additions were staggered by $30 \mathrm{~min}$ (Fig. $9 A-C$ ) (BDNF was followed by CHX 30 min later, and CNP was added 30 min after that). $\mathrm{CHX}$ did not affect proliferation in control cultures.

\section{CNP inhibits BDNF-induced activation of MAPK}

BDNF is known to stimulate the Ras-MAPK pathway (Nakamura et al., 1996; You et al., 2000), which has been confirmed in our ORN cultures. Although NGF is also known to stimulate this pathway, we have chosen to confine our examination of signal transduction to BDNF-stimulated pathways because of the more concise time course of BDNF action, and because BDNF produces a more robust proliferative response. To determine whether this pathway mediated BDNF-induced proliferation, we included the MEK inhibitor, PD98059 (Alessi et al., 1995; Dudley et al., 1995), in our cultures 30 min before treatment with BDNF and CNP alone or in combination (Fig. 9B). PD98059 caused a $43 \%$ inhibition in BDNF-induced BrdU labeling of neurons $(p<$ 0.001). Thus, BDNF acts, at least in part, through the MAPK pathway to mediate its proliferation-inducing effect. Surprisingly, PD98059 also blocked the ability of CNP to inhibit the BDNF response. This suggests that CNP also uses the MAPK pathway to exert its effects.

Because the results obtained using the MEK inhibitor suggested that BDNF might act through stimulation of the MAPK pathway to induce proliferation, we examined the effects of BDNF and CNP on various components of the MAPK signal transduction pathway using Western blots (Fig. 9C). After $30 \mathrm{~min}$, BDNF treatment increased MAPK (ERK1/2) phosphorylation. Treatment of cultures with CNP and BDNF together partially inhibited BDNF-stimulated MAPK phosphorylation by $30 \mathrm{~min}$ of treatment; after $2 \mathrm{hr}$, this combination treatment completely abolished the effect of BDNF alone. Thus, CNP may act through two mechanisms to inhibit BDNF-induced precursor proliferation: CNP interferes with MAPK signaling early, within $30 \mathrm{~min}$, perhaps by competition for MAPK signaling components and also affects protein synthesis. A mechanism that explains these results is presented in Figure 9D.

\section{BDNF and CNP alter the expression of cell-cycle-associated proteins}

If BDNF and CNP regulate proliferation and differentiation in ORNs, they should also alter the activation and/or expression of cell-cycle-associated proteins. To examine this, we determined the effects of BDNF and CNP on several cell-cycle-associated proteins, including PCNA, Cdk2, and p21 (Fig. 10). PCNA is a DNA sliding-clamp protein that acts as a DNA polymerase processivity factor and is also required for DNA synthesis during the S phase of the cell cycle (Tsurimoto, 1999). PCNA also interacts with several cell-cycle regulatory proteins such as the cyclin D1/Cdk complex and both p53 and p21, which inhibit DNA replication (Tsurimoto, 1999). Based on BrdU labeling results presented previously, we predicted that PCNA levels would be increased with exposure of ORNs to BDNF, and that this increase would be inhibited by simultaneous exposure to CNP. This was examined by two methods, Western blot analysis and PCNA/NST immunocytochemical double labeling followed by cell counting. Both of these results confirmed our hypothesis (Fig. $10 A, B)$. Exposure of ORNs to BDNF resulted in a dramatic increase in PCNA levels within $30 \mathrm{~min}$, and this increase was completely inhibited $2 \mathrm{hr}$ after the addition of CNP. These results were confirmed by cell-counting experiments at the $2 \mathrm{hr}$ time point, which revealed the same pattern of effect. Quantification of these results also demonstrated that differences seen in PCNA levels in response to different treatments were statistically significant (BDNF vs controls, $p<0.01$; BDNF vs BDNF/CNP, $p<$ 0.001). In contrast to PCNA, Cdk2 showed no change in expression levels when detected by either Western blot or Cdk2/NST immunocytochemistry (data not shown). This is perhaps not 

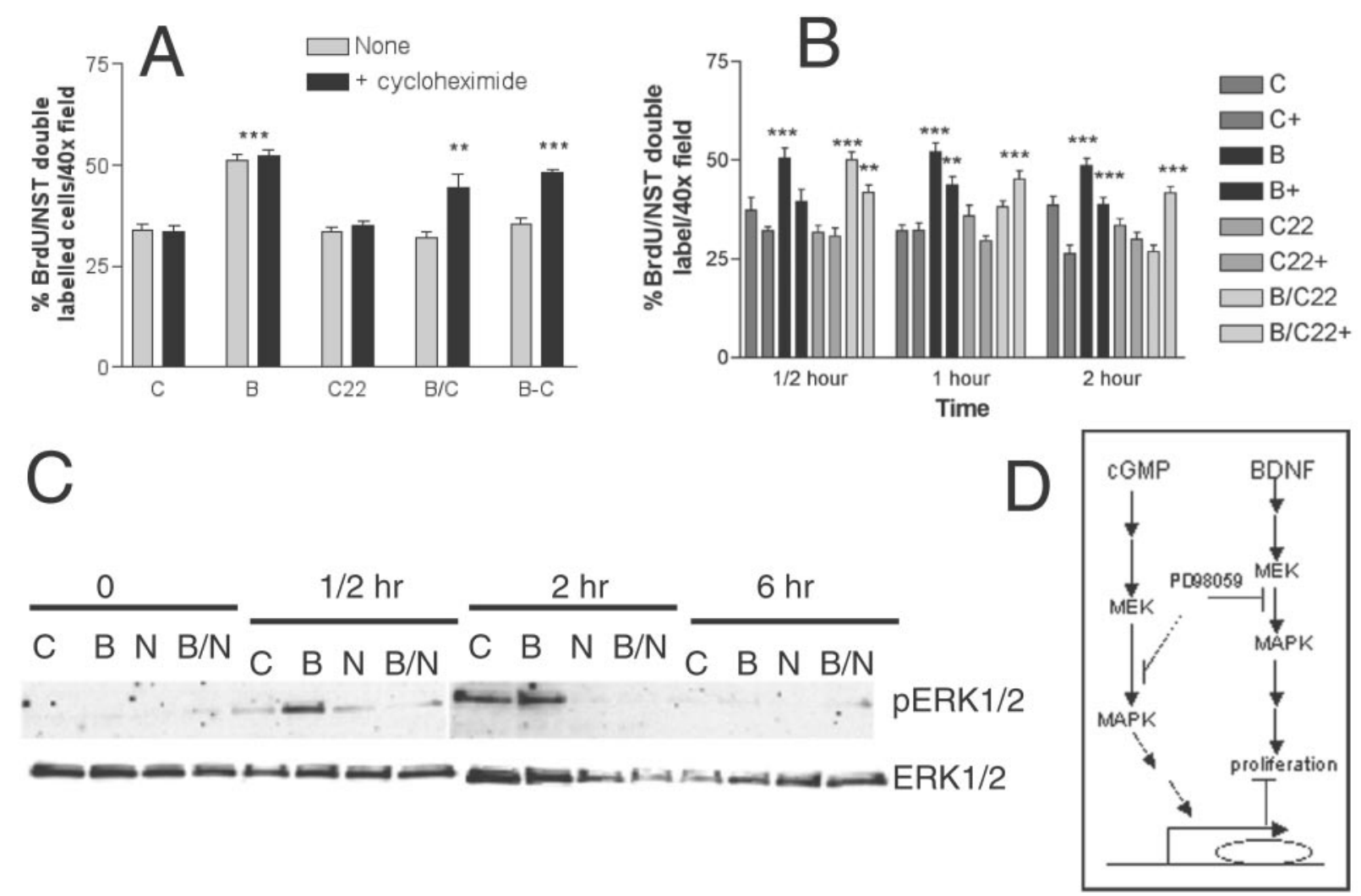

Figure 9. The effect of CNP on BDNF-induced BrdU incorporation is blocked by inhibition of protein synthesis with CHX or by the inhibition of MEK. Primary cultures were prepared and treated with control medium or medium containing BDNF or CNP alone or in combination, and with or without CHX or PD98059 as indicated. BrdU incorporation and immunostaining for NST were then performed on fixed slides. $A$, The effect of $10 \mathrm{mg} / \mathrm{ml}$ $\mathrm{CHX}$ on the ability of CNP to inhibit BDNF-induced BrdU incorporation in NST-positive neurons. $B$, The effects of BDNF and CNP either alone or together on BrdU incorporation in NST-positive neurons in the presence $(+)$ or absence of the MEK inhibitor PD98059. PD98059 inhibited BDNF-induced BrdU incorporation by $43 \%$ at the 30 min time point, and this level of inhibition remained constant for the remainder of the time course. PD98059 also inhibited the ability of CNP to block BDNF-induced BrdU incorporation, although over a longer time course; at 30 min the MEK inhibitor had no effect on CNP/BDNF, but by $2 \mathrm{hr}$ it had completely inhibited the ability of CNP to block the effects of BDNF. Statistics were calculated by ANOVA followed by Student's $t$ tests; ${ }^{* *} p<0.001$; ${ }^{* *} p<0.0001 . n=15$ counts per well, two wells per treatment from triplicate experiments. $C$, Western blot analysis of MAPK phosphorylation (pERK1/2) in response to CNP and BDNF alone or together ( $C$, no treatment; $B$, BDNF; $N$, CNP; $B / N, \mathrm{BDNF}$ and CNP). Nonphosphorylated MAPK (ERK1/2) serves as a loading control. $D$, Schematic of signal transduction events that could explain the above findings: BDNF activates the MAPK signal transduction pathway through binding to Trk B leading directly to stimulation of BrdU incorporation or proliferation. PD98059 blocks this response by 43\%. cGMP also stimulates MAPK signaling through an as yet unknown mechanism, albeit to a lesser extent than BDNF. Stimulation of this pathway by cGMP leads to an alteration in gene expression within $2 \mathrm{hr}$ after its application. It is alteration of this gene product by cGMP that ultimately interferes with the ability of BDNF to increase neuronal BrdU incorporation. The inclusion of either PD98059, which blocks cGMP-stimulated MAPK pathway activity, or CHX, which blocks protein synthesis, inhibits the effects of CNP on BDNF.

surprising, because $\mathrm{Cdk} 2$ is regulated by phosphorylation as well as by its level of expression.

\section{DISCUSSION}

In this study, we sought to identify factors that mediate the switch from proliferation to differentiation during postnatal neurogenesis using the olfactory system as a model. We provide evidence that BDNF and NGF are neuroproliferation-inducing factors whose unopposed actions result in the quiescence and apoptosis of daughter olfactory neurons and basal cells, respectively. CNP is identified as a factor that can act on these neuronal precursors when primed by BDNF or NGF, and mediates their differentiation and survival (Fig. 11). CNP appears to act through at least two signaling mechanisms. CNP alters neurotrophin-induced MAPK signaling and requires protein synthesis to execute these switches in cell cycle and cell phenotype.

We have shown that BDNF induces the proliferation and survival of neuronal precursor cells/immature neurons in the olfactory system in vivo and in vitro using BDNF null mice and an olfactory epithelium culture system, respectively. Within the ol- factory epithelium, the proliferation of neuronal cells involves the proliferation of basal cells to produce daughter cells and the subsequent migration of these daughter cells out of the basal layer, followed by their rapid proliferation to produce immature neurons (Mackay-Sim and Kittel, 1991). BDNF appears to act on daughter cells rather than on basal cells themselves, based on its rapid temporal effect on proliferation (within $30 \mathrm{~min}$ of treatment) and on alterations in nestin and Ki67 staining in the olfactory epithelium of BDNF null mice. This hypothesis is supported by localization studies showing that BDNF is found in basal cells (Buckland and Cunningham, 1999), whereas its receptor is localized to the region above the basal layer, where basal daughter cells are found (Roskams et al., 1996). Thus, we propose that BDNF is released by basal cells to trigger the proliferation of daughter cells that then become quiescent until they receive additional instruction from another factor that signals maturation (Fig. 11).

NGF induces proliferation of olfactory neuronal precursors in cell culture, but with a different time course, suggesting that NGF 

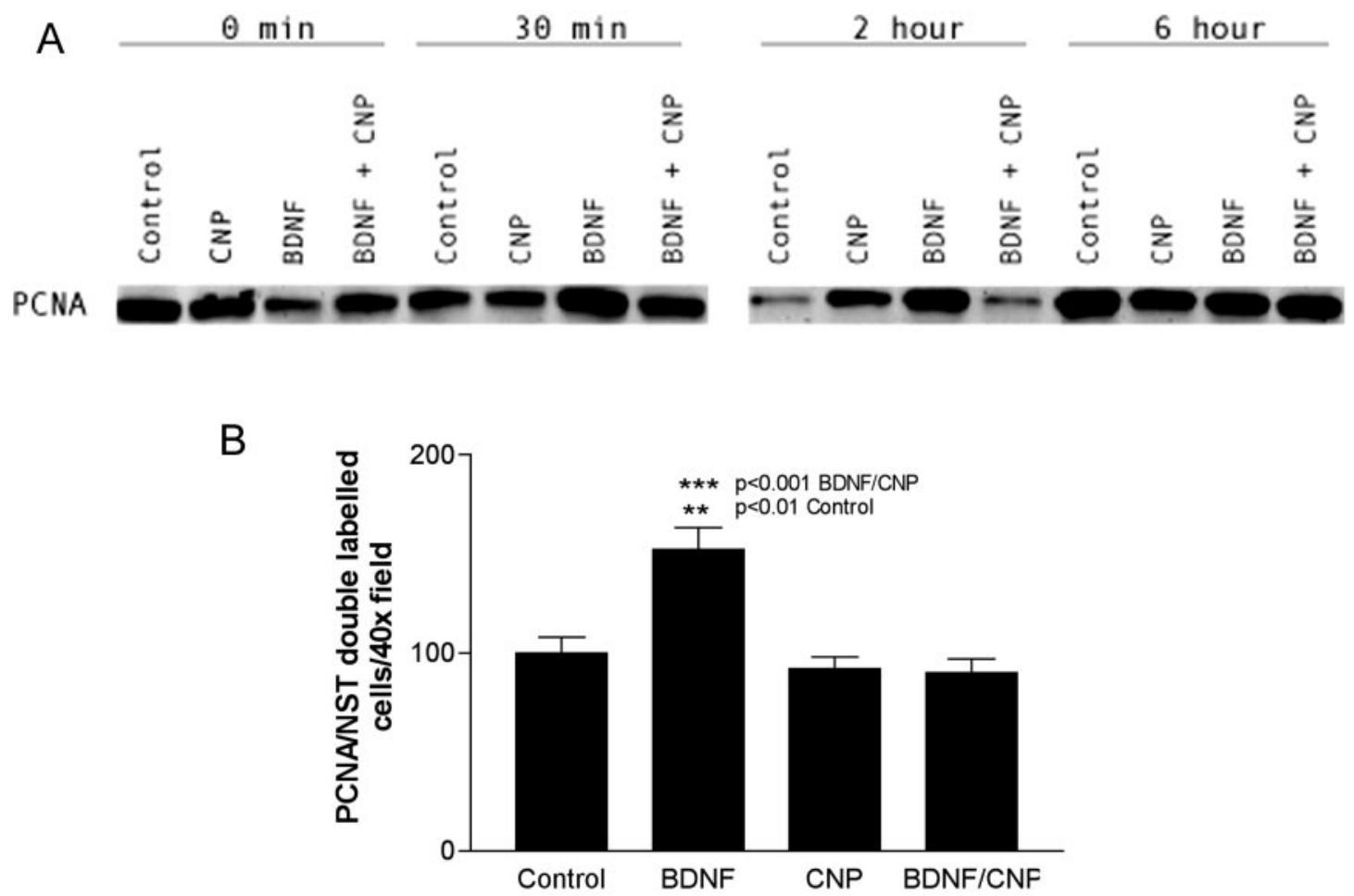

Figure 10. BDNF and CNP alter levels of PCNA expression. $A$, Western blot analysis of PCNA levels in response to CNP and BDNF alone or together over a $6 \mathrm{hr}$ time course. Note that the reduction in control levels at the $2 \mathrm{hr}$ time course is probably caused by reduced proliferation after transfer to $0.5 \%$ FBS feeding media. $B$, The effect of BDNF and CNP either alone or together on PCNA/NST double-labeled neurons 2 hr after application. $p$ values are shown on the graph. Statistics were performed as described above. $n$ represents 15 counts per well, two wells per treatment from triplicate experiments.

may act on a different target. NGF is not detected in the normal olfactory epithelium but is upregulated after lesioning of the olfactory bulb, which causes massive olfactory neuronal apoptosis and a compensatory increase in olfactory neurogenesis (Roskams et al., 1996). In the postbulbectomy olfactory epithelium, NGF is associated with more mature cells within the olfactory epithelium, whereas its receptor is found on basally positioned cells (Roskams et al., 1996; Miwa et al., 1998). This suggests that NGF acts directly on basal cells as a signal for proliferation to induce repopulation of the olfactory epithelium after injury (Fig. 11). Thus, NGF may act as a neuroproliferation-inducing signal during regeneration, when it appears to be released from dying neurons during the wave of target-deprived ORN apoptosis (Roskams et al., 1996).

After NGF-induced proliferation, at least a subset of NGFtreated cells undergoes apoptosis. Our hypothesis that BDNF acts later in the ORN life cycle than NGF suggests that subsequent exposure to BDNF might rescue these cells and allow their continued proliferation/survival. Sequential dependence on neurotrophins has been shown to occur in many systems, including sensory and sympathetic neurons (Davies, 1994). Previous work by others (Nef et al., 2001) has suggested that BDNF and NT-3 are not necessary for normal embryonic development of the olfactory epithelium, as measured by the ability of the epithelium to form and the presence of ORN axons in the olfactory bulb. Our work, however, suggests that BDNF, as well as NGF, plays a role in maintaining a homeostatic neuronal population in the olfactory epithelium postnatally.

CNP was able to inhibit both BDNF- and NGF-induced proliferation of NST-positive neurons. The fact that CNP acts on both BDNF- and NGF-treated cells suggests that it may act on at least two developmentally distinct populations, basal cells and their proliferating daughter cells. Furthermore, CNP promotes the differentiation of BDNF-treated neurons, based on process outgrowth analysis and its ability to increase the number of OMP-labeled mature neurons in culture. CNP also appears to promote survival of these cells and is able to save NGF-treated cells from subsequent apoptosis. In the case of NGF-treated cells, we also suspect that CNP induces differentiation to the next natural check point in maturation, the formation of daughter neurons. In the absence of specific markers for this stage, however, we cannot definitively demonstrate this activity. This role is supported by process outgrowth data, which show that treatment with CNP and NGF increases process outgrowth only to control values and not above, suggesting that additional maturation occurs normally.

We suggest that NGF, BDNF, and CNP may act in a sequential or combinatorial pattern to promote the maturation of ORNs within the olfactory epithelium. Specifically, NGF acts to promote basal cell proliferation to form daughter cells, BDNF acts to promote rapid proliferation of daughter cells, and CNP acts on either cell type to promote differentiation to the next maturational checkpoint. Previous work has shown that checkpoints exist subsequent to both basal and daughter cell proliferation within the olfactory epithelium (Calof et al., 1998). It also has been shown that the presence of a large number of differentiated neurons in culture with ORN basal cells inhibits their proliferation (Calof et al., 1998). It may be that this inhibitory factor is CNP. That CNP would act only on cells previously induced to proliferate by exposure to growth factors seems logical, in that 


\section{OLFACTORY EPITHELIUM}

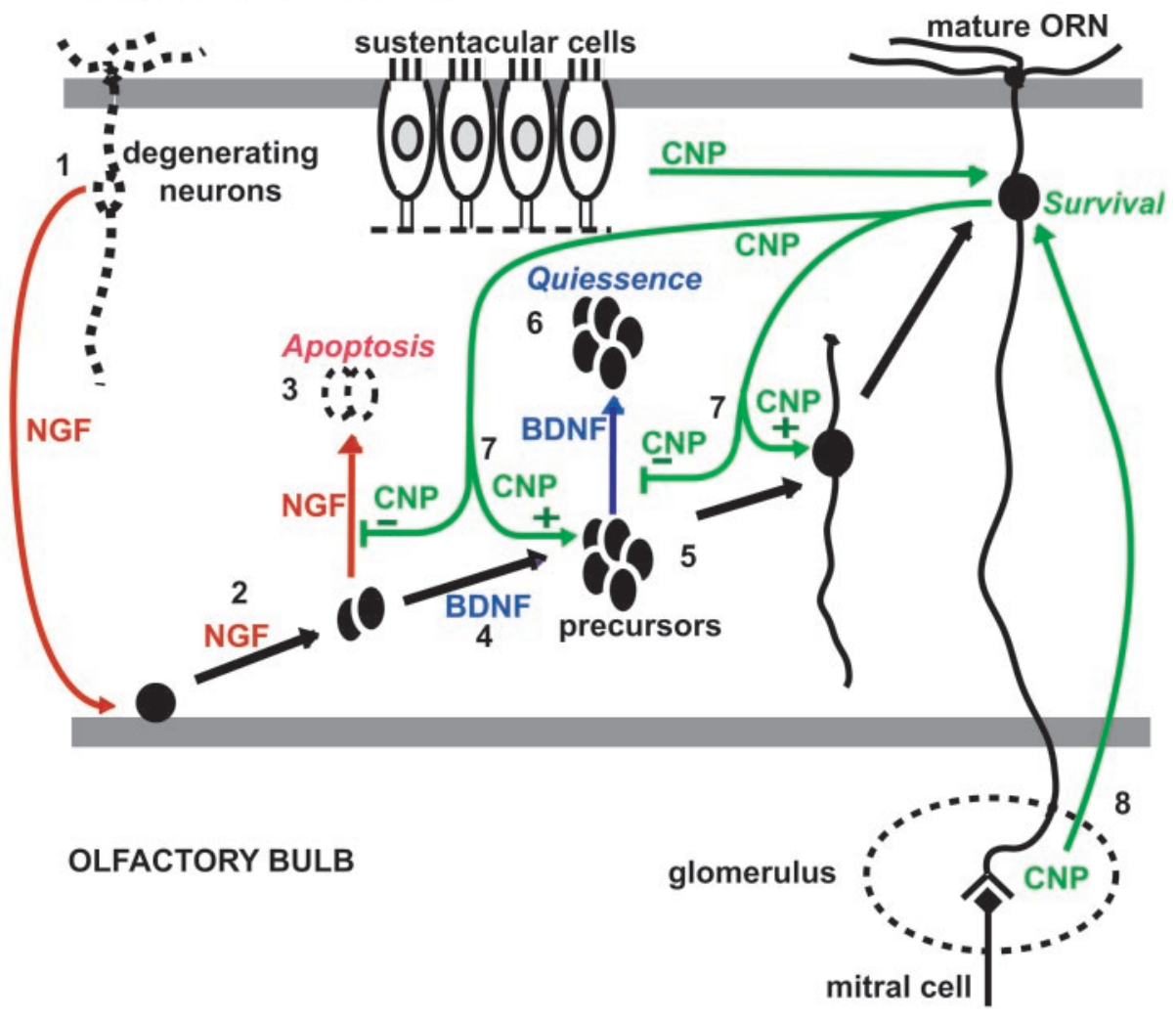

Figure 11. Model of BDNF, NGF, and CNP actions in the olfactory system. 1, NGF is released from apoptotic cells within the regenerating olfactory epithelium and acts on basal cells to promote their division to form basal daughter cells that then migrate to a region slightly above the basal layer (2). 3, In the absence of other factors, these cells then undergo apoptosis. 4, BDNF is released from cells within the basal layer and acts on basal daughter cells to allow them to undergo further rapid proliferation (5). 6 , In the absence of other factors, these cells become quiescent. 7 , CNP can act at either the level of the basal cells or their daughter cells to inhibit growth factor-induced proliferation and promote cell differentiation to the next stage of maturation. CNP by itself has no effect. CNP appears to be released from mature cells within the olfactory epithelium at P1, and later by sustentacular cells in the adult animal. $8, \mathrm{CNP}$ also promotes the survival of more mature, OMP-positive neurons within the olfactory epithelium, perhaps through its presence in the olfactory bulb. Within less mature animals (P1), CNP appears within the forming glomeruli and mitral cell layer, whereas in the adult it appears in the periglomerular cells surrounding each glomeruli and also in the mitral cell region. unregulated proliferation of these cells would be detrimental for maintenance of a homeostatic population of ORNs within the olfactory epithelium. Thus, the effect of CNP may be viewed as a form of autoregulation that takes place within the olfactory epithelium to maintain a homeostatic population.

The effect of CNP on BDNF- or NGF-treated cells appears to be specific for CNP and is not mimicked by either ANP or BNP (data not shown). It is, however, mimicked by 8-bromo-cGMP. Previous work has suggested that cGMP has both mitogenic and anti-mitogenic effects. Transient increases in cGMP are seen after reinitiation of growth in quiescent fibroblasts (Rudland et al., 1974). Alternatively, nitric oxide (NO) donors, acting through stimulation of soluble guanylyl cyclase and the subsequent production of cGMP, have anti-mitogenic effects and potentiate the development of catecholaminergic traits in cultures of chick sympathetic neurons (Zurn, 1991). cGMP-stimulated PKG and PKA activities have been shown to both stimulate and inhibit MAPK pathway activity (Browning et al., 2000; Gudi et al., 2000; Schwarz et al., 2000). PKG has been implicated as both a mitogenic and anti-mitogenic mediator (Hindley et al., 1997; Firestein and Bredt, 1998), whereas PKA has been suggested to play an antimitotic role (Cornwell et al., 1994). cGMP analogues have also been shown to prevent spinal cord motor neuron apoptosis during the period of programmed cell death (Weill and Greene, 1984). Our data support all of these roles for cGMP, suggest that they may even occur in the same cell type, depending on cellular environment, and provide a context for the pleiotrophic effects seen in response to many factors. In the absence of BDNF, CNP either has no effect or occasionally shows a modest proliferative effect on ORNs in culture; however, in the presence of either BDNF or NGF, CNP displays strong anti-mitogenic effects.

We have examined the mechanisms that mediate the actions of these factors in ORN precursors. Addition of the MEK inhibitor PD987059 inhibits the ability of BDNF to induce proliferation by $\sim 50 \%$. Western blot analysis also reveals that CNP blocks BDNF-induced MAPK phosphorylation within $30 \mathrm{~min}$. However, CNP requires at least $1-2 \mathrm{hr}$ to inhibit BDNF-induced proliferation, suggesting that additional steps are involved. CNP also requires protein synthesis to exert its affects on BDNF- and NGF-induced proliferation. CHX blocks the ability of CNP to inhibit neurotrophin-induced proliferation $2 \mathrm{hr}$ after addition. The mechanism that leads to this alteration of protein expression has not been completely explored; however, the time course of MEK inhibitor action suggests that activation of the MAPK pathway precedes this step. Previous work in this laboratory has shown that cGMP analogues are able to promote cAMP response element-binding protein (CREB) phosphorylation through their subsequent elevation of CAMP levels and activation of PKA (Moon et al., 1999), and others have suggested that both cGMPstimulated activation of adenylyl cyclase and PKG may lead to CREB phosphorylation and alteration of gene expression (Moon et al., 1999; Gudi et al., 2000). Some candidate products for CNP-induced gene expression are cell-cycle regulatory proteins.

Our findings demonstrate a role for BDNF, NGF, and CNP in regulating neurogenesis in the olfactory epithelium. These results should be especially relevant to stem cell research in the hippocampus, where both factors are present, and application of BDNF leads to only partial process outgrowth from stem cells (Shetty and Turner, 1999). In addition, NO donors that cause the production of cGMP through stimulation of soluble guanylyl have already been shown to promote increased neurite outgrowth in hippocampal cell lines (Hindley et al., 1997). Although in this case no additional growth factor was added, these cells were cocultured with astrocytes, a potential source of unidentified 
trophic factors. It may be that CNP is the endogenous source of cGMP production in these neurons. The existence of high levels of CNP and GC-B throughout the brain suggests developmental roles for this peptide and its receptor in a variety of neuronal cell types.

\section{REFERENCES}

Abe K (2000) Therapeutic potential of neurotrophic factors and neural stem cells against ischemic brain injury. J Cereb Blood Flow Metab 20:1393-1408.

Ajiro K, Yoda K, Utsumi K, Nishikawa Y (1996) Alteration of cell cycle-dependent histone phosphorylations by okadaic acid. Induction of mitosis-specific H3 phosphorylation and chromatin condensation in mammalian interphase cells. J Biol Chem 271:13197-13201.

Alessi DR, Cuenda A, Cohen P, Dudley DT, Saltiel AR (1995) PD 098059 is a specific inhibitor of the activation of mitogen-activated protein kinase kinase in vitro and in vivo. J Biol Chem 270:27489-27494.

Anastasiadis PZ, Bezin L, Imerman BA, Kuhn DM, Louie MC, Levine RA (1997) Tetrahydrobiopterin as a mediator of PC12 cell proliferation induced by EGF and NGF. Eur J Neurosci 9:1831-1837.

Barber RD, Jaworsky DE, Yau K-W, Ronnett GV (2000) Isolation and in vitro differentiation of conditionally immortalized murine olfactory receptor neurons. J Neurosci 20:3695-3704.

Bayer S, Altman J (1995) Neurogenesis and neuronal migration. In: The rat nervous system (Paxinos G, ed), pp 1041-1078. London: Academic.

Brown J, Zuo Z (1995) Natriuretic peptide receptors in the fetal rat. Am J Physiol 269:E253-E268.

Browning DD, McShane MP, Marty C, Ye RD (2000) Nitric oxide activation of p38 mitogen-activated protein kinase in $293 \mathrm{~T}$ fibroblasts requires cGMP-dependent protein kinase. J Biol Chem 275:2811-2816.

Buckland M, Cunningham AM (1998) Alterations in the neurotrophic factors BDNF, GDNF, and $\mathrm{CNTF}$ in the regenerating olfactory system. Ann NY Acad Sci 855:260-265.

Buckland M, Cunningham AM (1999) Alterations in expression of the neurotrophic factors glial cell line-derived neurotrophic factor, ciliary neurotrophic factor, and brain-derived neurotrophic factor, in the target deprived olfactory neuroepithelium. Neuroscience 90:333-347.

Calderone A, Thaik CM, Takahashi N, Chang DL, Colucci WS (1998) Nitric oxide, atrial natriuretic peptide, and cyclic GMP inhibit the growth-promoting effects of norepinephrine in cardiac myocytes and fibroblasts. J Clin Invest 101:812-818.

Calof AL, Rim PC, Askins KJ, Mumm JS, Gordon MK, Iannuzzelli P, Shou J (1998) Factors regulating neurogenesis and programmed cell death in mouse olfactory epithelium. Ann NY Acad Sci 855:226-229.

Calza L, Giardino L, Pozza M, Bettelli C, Micera A, Aloe L (1998) Proliferation and phenotype regulation in the subventricular zone during experimental allergic encephalomyelitis: in vivo evidence of a role for nerve growth factor. Proc Natl Acad Sci USA 95:3209-3214.

Chinkers M, Garbers DL (1991) Signal transduction by guanylyl cyclases. Annu Rev Biochem 60:553-575.

Chinkers M, Chang DL, Lowe M-S, Chin H, Goeddel DV, Schulz S (1989) A membrane form of guanylate cyclase is an atrial natriuretic peptide receptor. Nature 338:78-83.

Chrisman TD, Garbers DL (1999) Reciprocal antagonism coordinates C-type natriuretic peptide and mitogen-signaling pathways in fibroblasts. J Biol Chem 274:4293-4299.

Constanzo RM (1984) Comparison of neurogenesis and cell replacement in the hamster olfactory system with and without a target (olfactory bulb). Brain Res 307:295-301.

Cornwell TL, Arnold E, Boerth NJ, Lincoln TM (1994) Inhibition of smooth muscle cell growth by nitric oxide and activation of cAMPdependent protein kinase by cGMP. Am J Physiol 267:C1405-C1413.

Cunningham AM, Manis PB, Reed RR, Ronnett GV (1999) Olfactory receptor neurons exist as distinct subclasses of immature and mature cells in primary culture. Neuroscience 93:1301-1312.

Davies AM (1994) The role of neurotrophins during successive stages of sensory neuron development. Prog Growth Factor Res 5:263-289.

Dudley DT, Pang L, Decker SJ, Bridges AJ, Saltiel AR (1995) A synthetic inhibitor of the mitogen-activated protein kinase cascade. Proc Natl Acad Sci USA 92:7686-7689.

Edwards BE, Gearhart JD, Wallach EE (2000) The human pluripotent stem cell: impact on medicine and society. Fertil Steril 74:1-7.

Firestein BL, Bredt DS (1998) Regulation of sensory neuron precursor proliferation by cyclic GMP-dependent protein kinase. J Neurochem 71:1846-1853.

Fulle H-J, Vassar R, Foster DC, Yang R-B, Axel R, Garbers DL (1995) A receptor guanylyl cyclase expressed specifically in olfactory sensory neurons. Proc Natl Acad Sci USA 92:3571-3575.

Geffen R, Goldstein RS (1996) Rescue of sensory ganglia that are programmed to degenerate in normal development: evidence that NGF modulates proliferation of DRG cells in vivo. Dev Biol 178:51-62.

Goldstein RS, Avivi C, Geffen R (1997) In vivo NGF treatment in- creases proliferation in the primary sympathetic ganglia of chick embryos. Dev Biol 181:116-120.

Graziadei PPC, Monti-Graziadei M (1978) The olfactory system: a model for the study of neurogenesis and axon regeneration in mammals. In: Neuronal plasticity (Cotman CW, ed), pp 131-153. New York: Raven.

Graziadei PPC, Monti-Graziadei GA (1979) Neurogenesis and neuron regeneration in the olfactory system of mammals. J Neurocytol 8:1-18.

Graziadei PPC, Monti-Graziadei GA (1983) Regeneration in the olfactory system of vertebrates. Am J Otolaryngol 4:228-233.

Gudi T, Casteel DE, Vinson C, Boss GR, Pilz RB (2000) NO activation of fos promoter elements requires nuclear translocation of G-kinase I and CREB phosphorylation but is independent of MAP kinase activation. Oncogene 19:6324-6333.

Hansel DE, Eipper BA, Ronnett GV (2001a) Neuropeptide Y functions as a neuroproliferative factor. Nature 410:940-944.

Hansel DE, May V, Eipper BA, Ronnett GV (2001b) PACAP peptides and $\alpha$-amidation in olfactory neurogenesis and neuronal survival in vitro. J Neurosci 21:4625-4636.

Herman JP, Dolgas CM, Rucker D, Langub MC (1996) Localization of natriuretic peptide-activated guanylate cyclase mRNAs in the rat brain. J Comp Neurol 369:165-187.

Hindley S, Juurlink BH, Gysbers JW, Middlemiss PJ, Herman MA, Rathbone MP (1997) Nitric oxide donors enhance neurotrophininduced neurite outgrowth through a cGMP-dependent mechanism. J Neurosci Res 47:427-439.

Holcomb JD, Mumm JS, Calof AL (1995) Apoptosis in the neuronal lineage of the mouse olfactory epithelium: regulation in vivo and in vitro. Dev Biol 172:307-323.

Huard JM, Youngentob SL, Goldstein BJ, Luskin MB, Schwob JE (1998) Adult olfactory epithelium contains multipotent progenitors that give rise to neurons and non-neural cells. J Comp Neurol 400:469-486.

Jaworsky DE, Matsuzaki O, Borisy FF, Ronnett GV (1995) Calcium modulates the rapid kinetics of the odorant-induced cyclic AMP signal in rat olfactory cilia. J Neurosci 15:310-318.

Jiang H, Movsesyan V, Fink Jr DW, Fasler M, Whalin M, Katagiri Y, Monshipouri M, Dickens G, Lelkes PI, Guroff G, Lazarovici P (1997) Expression of human p140trk receptors in p140trk-deficient, PC12/ endothelial cells results in nerve growth factor-induced signal transduction and DNA synthesis. J Cell Biochem 66:229-244.

Kastner A, Moyse E, Bauer S, Jourdan F, Brun G (2000) Unusual regulation of cyclin D1 and cyclin-dependent kinases cdk2 and cdk4 during in vivo mitotic stimulation of olfactory neuron progenitors in adult mouse. J Neurochem 74:2343-2349.

Laemmli UK (1970) Cleavage of structural proteins during the assembly of the head of bacteriophage T4. Nature 227:680-685.

Langub MC, Dolgas CM, Watson RE, Herman JP (1995) The C-type natriuretic peptide receptor is the predominant natriuretic peptide receptor mRNA expressed in rat hypothalamus. J Neuroendocrinol 7:305-309.

Learish RD, Bruss MD, Haak-Frendscho M (2000) Inhibition of mitogen-activated protein kinase kinase blocks proliferation of neural progenitor cells. Brain Res Dev Brain Res 122:97-109.

Lee VM, Pixley SK (1994) Age and differentiation-related differences in neuron-specific tubulin immunostaining of olfactory sensory neurons. Brain Res Dev Brain Res 83:209-215.

Liebl DJ, Tessarollo L, Palko ME, Parada LF (1997) Absence of sensory neurons before target innervation in brain-derived neurotrophic factor-, neurotrophin 3-, and TrkC-deficient embryonic mice. J Neurosci 17:9113-9121.

Mackay-Sim A, Kittel PW (1991) Cell dynamics in the adult mouse olfactory epithelium: a quantitative autoradiographic study. J Neurosci 11:979-984.

Mackay-Sim A, Chuah MI (2000) Neurotrophic factors in the primary olfactory pathway. Prog Neurobiol 62:527-559.

Mahadevan LC, Willis AC, Barratt MJ (1991) Rapid histone H3 phosphorylation in response to growth factors, phorbol esters, okadaic acid, and protein synthesis inhibitors. Cell 65:775-783.

Margolis FL (1985) Olfactory marker protein: from PAGE band to cDNA clone. Trends Neurosci 8:542-546.

Miwa T, Horikawa I, Uramoto N, Ishimaru T, Yamamoto K, Furukawa M, Kato T, Moriizumi T (1998) TrkA expression in mouse olfactory tract following axotomy of olfactory nerves. Acta Otolaryngol Suppl 539:79-82.

Miyazawa K, Himi T, Garcia V, Yamagishi H, Sato S, Ishizaki Y (2000) A role for p27/Kip1 in the control of cerebellar granule cell precursor proliferation. J Neurosci 20:5756-5763.

Moon C, Sung YK, Reddy R, Ronnett GV (1999) Odorants induce the phosphorylation of the cAMP response element binding protein in olfactory receptor neurons. Proc Natl Acad Sci USA 96:14605-14610.

Morrison EE, Costanzo RM (1990a) Morphology of the human olfactory epithelium. J Comp Neurol 297:1-13.

Morrison EE, Costanzo RM (1990b) Morphology of olfactory epithelium in humans and other vertebrates. Microscopy Res Tech 23:49-61. 
Morrison EE, Moran DT (1995) Anatomy and ultrastructure of the human olfactory neuroepithelium. In: Handbook of olfaction and gustation (Doty RL, ed), pp 75-101. New York: Marcel Dekker.

Nakamura T, Sanokawa R, Sasaki Y, Ayusawa D, Oishi M, Mori N (1996) N-Shc: a neural-specific adapter molecule that mediates signaling from neurotrophin/Trk to Ras/MAPK pathway. Oncogene 13:1111-1121.

Nef S, Lush ME, Shipman TE, Parada LF (2001) Neurotrophins are not required for normal embryonic development of olfactory neurons. Dev Biol 234:80-92.

Osada T, Ichikawa M, Costanzo RM (1995) In nestin a marker for chemosensory precursor cells? Brain Res 683:254-257.

Porter JG, Catalano R, McEnroe G, Lewicki JA, Protter AA (1992) C-type natriuretic peptide inhibits growth factor-dependent DNA synthesis in smooth muscle cells. Am J Physiol 263:C1001-C1006.

Rijzewijk JJ, Erp PEV, Bauer FW (1989) Two binding sites for Ki67 related to quiescent and cycling cells in human epidermis. Acta Derm Venereol 69:512-515.

Ronnett GV, Hester LD, Snyder SH (1991) Primary culture of neonatal rat olfactory neurons. J Neurosci 11:1243-1255.

Ronnett GV, Cho H, Hester LD, Wood SF, Snyder SH (1993) Odorants differentially enhance phosphoinositide turnover and adenylyl cyclase in olfactory receptor neuronal cultures. J Neurosci 13:1751-1758.

Roskams AJ, Bethel MA, Hurt KJ, Ronnett GV (1996) Sequential expression of Trks $\mathrm{A}, \mathrm{B}$, and $\mathrm{C}$ in the regenerating olfactory neuroepithelium. J Neurosci 16:1294-1307.

Roskams AJI, Cai X, Ronnett GV (1998) Expression of neuron-specific $\beta$-III tubulin during olfactory neurogenesis in the embryonic and adult rat. Neuroscience 83:191-200.

Rosser AE, Tyers P, Dunnett SB (2000) The morphological development of neurons derived from EGF- and FGF-2-driven human CNS precursors depends on their site of integration in the neonatal rat brain. Eur J Neurosci 12:2405-2413.

Rudland PS, Seeley M, Seifert W (1974) Cyclic GMP and cyclic AMP levels in normal and transformed fibroblasts. Nature 251:417-419.

Ryan MC, Gundlach AL (1998) Ontogenic expression of natriuretic peptide mRNAs in postnatal rat brain: implications for development? Brain Res Dev Brain Res 105:251-268.

Schultz E (1960) Repair of olfactory mucosa, with special reference to regeneration of olfactory cells (sensory neurones). Am J Pathol $37: 1-19$.

Schwarz UR, Kobsar AL, Koksch M, Walter U, Eigenthaler M (2000) Inhibition of agonist-induced p42 and p38 mitogen-activated protein kinase phosphorylation and CD40 ligand/P-selectin expression by cyclic nucleotide-regulated pathways in human platelets. Biochem Pharmacol 60:1399-1407.

Shetty AK, Turner DA (1998) In vitro survival and differentiation of neurons derived from epidermal growth factor-responsive postnatal hippocampal stem cells: inducing effects of brain-derived neurotrophic factor. J Neurobiol 35:395-425.

Shetty AK, Turner DA (1999) Neurite outgrowth from progeny of epidermal growth factor-responsive hippocampal stem cells is significantly less robust than from fetal hippocampal cells following grafting onto organotypic hippocampal slice cultures: effect of brain-derived neurotrophic factor. J Neurobiol 38:391-413.

Sieber-Blum M (1998) Growth factor synergism and antagonism in early neural crest development. Biochem Cell Biol 76:1039-1050.

Sudoh T, Minamino N, Kangawa K, Matsuo H (1990) C-type natriuretic peptide (CNP): a new member of natriuretic peptide family identified in porcine brain. Biochem Biophys Res Commun 168:863-870.

Suzuki M, Kitanishi T, Kitano H, Yazawa Y, Kitajima K, Takeda T, Tokunaga Y, Maeda T, Kimura H, Tooyama I (2000) C-type natriuretic peptide-like immunoreactivity in the rat inner ear. Hear Res 139:51-58.

Thomson JA, Itskovitz-Eldor J, Shapiro SS, Waknitz MA, Swiergeil JJ, Marshall VS, Jones JM (1998) Embryonic stem cell lines derived from human blastocytes. Science 282:1145-1147.

Tohyama T, Lee VMY, Rorke LB, Marvin M, McKay RDG, Trojanowski JQ (1992) Nestin expression in embryonic human neuroepithelium and in human neuroepithelial tumor cells. Lab Invest 66:303313.

Tsurimoto T (1999) PCNA binding proteins. Front Biosci 4:D849-D858.

Uraih LC, Maronpot RR (1990) Normal histology of the nasal cavity and application of special techniques. Environ Health Perspect 85:187-208.

Vogel G (1999) Harnessing the power of stem cells. Science 283: $1432-1434$.

Vollmar AM, Schmidt KN, Schulz R (1996) Natriuretic peptide receptors on rat thymocytes: inhibition of proliferation by atrial natriuretic peptide. Endocrinology 137:1706-1713.

Wang MM, Reed RR (1993) Molecular cloning of the olfactory neuronal transcription factor Olf-1 by genetic selection in yeast. Nature 364:121-126.

Weill CL, Greene DP (1984) Prevention of natural motoneurone cell death by dibutyryl cyclic GMP. Nature 308:452-454.

You L, Kruse FE, Volcker HE (2000) Neurotrophic factors in the human cornea. Invest Ophthalmol Vis Sci 41:692-702.

Zimmerman L, Parr B, Lendahl U, Cunningham M, McKay R, Gavin B, Mann J, Vassileva G, McMahon A (1994) Independent regulatory elements in the nestin gene direct transgene expression to neural stem cells or muscle precursors. Neuron 12:11-24.

Zurn AD (1991) Catecholaminergic traits of chick sympathetic neurons may be differentially regulated by a cGMP-dependent pathway. Brain Res Dev Brain Res 58:105-110. 